\title{
Bayesian Network Analysis for the Questionnaire Investigation on the Needs at Fuji Shopping Street Town under the View Point of Service Engineering
}

\author{
Tsuyoshi Aburai ${ }^{1}$ \\ Tokushima University \\ Tokushima, JAPAN
}

\author{
Akane Okubo ${ }^{2}$ \\ University of Shizuoka, Japan \\ Shizuoka, JAPAN
}

\author{
Daisuke Suzuki ${ }^{3}$ \\ Fujisan Area Management Company \\ Shizuoka, JAPAN \\ Kazuhiro Takeyasu ${ }^{4}$ \\ College of Business Administration, Tokoha University, \\ Japan, Shizuoka, JAPAN
}

\begin{abstract}
Shopping streets at local city in Japan became old and are generally declining. In this paper, the area rebirth and/or regional revitalization of shopping street are handled. Fuji city in Japan is focused. Four big festivals are held at Fuji city (two for Fuji Shopping Street Town and two for Yoshiwara Shopping Street Town). Many people visit these festivals including residents in that area. Therefore a questionnaire investigation to the residents and visitors is conducted during these periods in order to clarify residents and visitors' needs for the shopping street, and utilize them to the plan building of the area rebirth and/or regional revitalization of shopping street. There is a big difference between Fuji Shopping Street Town and Yoshiwara Shopping Street Town. Therefore Fuji Shopping Street Town is focused in this paper. These are analyzed by using Bayesian Network. These are analyzed by sensitivity analysis and odds ratio is calculated to the results of sensitivity analysis in order to obtain much clearer results. The analysis utilizing Bayesian Network enabled us to visualize the causal relationship among items. Furthermore, sensitivity analysis brought us estimating and predicting the prospective visitors. Sensitivity analysis is performed by back propagation method. These are utilized for constructing a much more effective and useful plan building. Fruitful results are obtained. To confirm the findings by utilizing the new consecutive visiting records would be the future works to be investigated.
\end{abstract}

Keywords-Fuji city; area rebirth; regional vitalization; Bayesian network; back propagation; service engineering

\section{INTRODUCTION}

Shopping streets at local city in Japan are generally declining. It is because most of them were built in the so-called "High Growth Period (1954-1973)". Therefore they became old and area rebirth and/or regional revitalization are required everywhere.

There are many papers published concerning area rebirth or regional revitalization. Author in [1] has pointed out the importance of tourism promotion. Author in [2] developed the project of shutter art to Wakkanai Chuo shopping street in Hokkaido, Japan. Author in [3] has made a questionnaire research at Jigenji shopping street in Kagoshima Prefecture,
Japan and analyzed the current condition and future issues. For about tourism, many papers are presented from many aspects as follows.

Author in [4] designed and conducted a visitor survey on the spot, which used a questionnaire to investigate the activities of visitors to the Ueno district in Taito ward, Tokyo. Author in [5] analyzed the image of the Izu Peninsula as a tourist destination in their 2003 study "Questionnaire Survey on the Izu Peninsula." Author in [6] conducted tourist behavior studies in Atami city in 2008, 2009, 2014 and in other years.

In this paper, the area rebirth and/or regional revitalization of shopping street are handled. Fuji city in Japan is focused. Fuji city is located in Shizuoka Prefecture. Mt. Fuji is very famous all around the world and its beautiful scenery from Fuji city can be seen, which is at the foot of Mt. Fuji. There are two big shopping streets in Fuji city. One is Yoshiwara shopping street and another one is Fuji shopping street. They became old and building area rebirth and regional revitalization plan have started. Following investigation was conducted by the joint research group (Fuji Chamber of Commerce \& Industry, Fujisan Area Management Company, Katsumata Maruyama Architects, Kougakuin University and Tokoha University). The main project activities are as follows:

- Investigation on the assets which are not in active use

- Questionnaire Investigation to Entrepreneur

- Questionnaire Investigation to the residents and visitors built.

After that, area rebirth and regional revitalization plan were

In this paper, above stated $\mathrm{C}$ is handled.

Four big festivals are held at Fuji city. Two big festivals are held at Yoshiwara Shopping Street Town and two big festivals at Fuji Shopping Street Town.

At Yoshiwara Shopping Street Town, Yoshiwara Gion Festival is carried out during June and Yoshiwara Shukuba (post-town) Festival is held during October. On the other hand, 
Kinoene Summer Festival is conducted during August and Kinoene Autumn Festival is performed during October at Fuji Shopping Street Town. Many people visit these festivals including residents in that area.

Therefore questionnaire investigation of $\mathrm{C}$ is conducted during these periods.

Finally, 982 sheets (Yoshiwara Shopping Street Town: 448, Fuji Shopping Street Town: 534) were obtained.

Basic statistical analysis and Bayesian Network analysis are executed based on that. This is really a quite new approach in this field and there is no related paper on this theme as far as searched.

In recent years, the Bayesian network is highlighted because it has the following good characteristics (Neapolitan, 2004).

- Structural Equation Modeling requires normal distribution to the data in the analysis. Therefore, it has a limitation in making analysis, but the Bayesian network does not require a specific distribution type to the data. It can handle any distribution type.

- It can handle the data which include partial data.

- Expert's know-how can be reflected in building a Bayesian Network model.

- Sensitivity analysis can be easily performed by settling evidence. The prospective purchaser can be estimated and predicted by that analysis.

- It is a probability model having a network structure. Related items are connected with directional link. Therefore, understanding becomes easy by its visual chart.

The field of service marketing generally handles the shapeless.

Therefore it is often the case that it is hard to catch the influence to consumers.

Bayesian Network analysis enables to visualize the relationship and/or influence of shapeless products to consumers which is the field of service marketing.

These are also applied to service engineering.

In this paper, a questionnaire investigation is executed in order to clarify residents and visitors' needs for the shopping street and utilize them to the plan building of the area rebirth and/or regional revitalization of shopping street. There is a big difference between Fuji Shopping Street Town and Yoshiwara Shopping Street Town. Therefore Fuji Shopping Street Town is focused in this paper. These are analyzed by using Bayesian Network. These are analyzed by sensitivity analysis and odds ratio is calculated to the results of sensitivity analysis in order to obtain much clearer results. By that model, the causal relationship is sequentially chained by the characteristics of visitors, the purpose of visiting and the image of the surrounding area at this shopping street. The analysis utilizing Bayesian Network enabled us to visualize the causal

relationship among items. Furthermore, sensitivity analysis brought us estimating and predicting the prospective visitors. Sensitivity analysis was conducted by back propagation method.

Some interesting and instructive results are obtained.

The rest of the paper is organized as follows. Outline of questionnaire investigation is stated in Section 2. In Section 3, Bayesian Network analysis is executed which is followed by the sensitivity analysis in Section 4. Conclusion is stated in Section 5.

\section{OUtLINE AND the Basic Statistical RESUlts OF THE QUESTIONNAIRE RESEARCH}

\section{A. Outline of the Questionnaire Research}

A questionnaire investigation to the residents and visitors is conducted during these periods in order to clarify residents and visitors' needs for the shopping street, and utilize them to the plan building of the area rebirth and/or regional revitalization of shopping street. The outline of questionnaire research is as follows. Questionnaire sheet is attached in Appendix 1.

Scope of
investigation

(3) Method

(4) Collection
Residents and visitors who have visited four big festivals at Fuji city in Shizuoka Prefecture, Japan Yoshiwara Gion Festival: June $11,12 / 2016$

Yoshiwara Shukuba (post-town) Festival: October 9/2016

Kinoene Summer Festival: August 6,7/2016

Kinoene Autumn Festival: October 15,16/2016

Local site, Dispatch sheet, Self writing

Number of distribution 1400

Number of collection

982(collection rate $70.1 \%$ )

Valid answer 982

\section{B. Basic Statistical Results}

Now, the main summary results by single variable are shown.

1) Characteristics of answers

a) Sex (Q7): Male 43.3\%, Female 56.7\%

These are exhibited in Fig. 1.

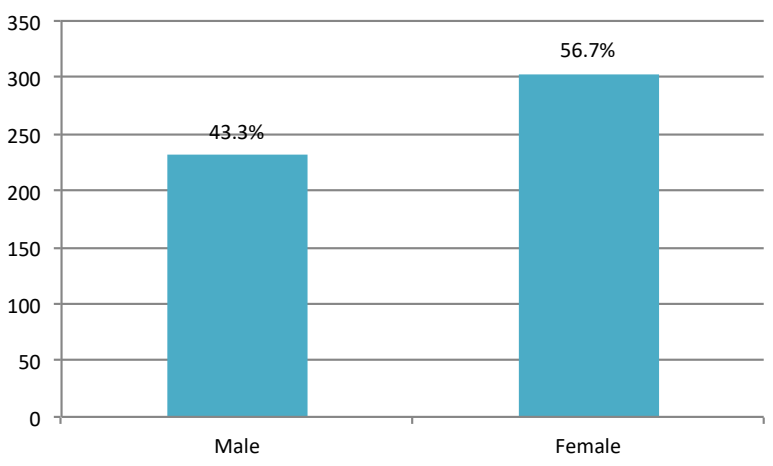

Fig. 1. Sex (Q7). 
b) Age (Q8): 10th 20.6\%, 20th $16.7 \%$, 30th $25.3 \%$, 40th $17.0 \%$, 50th $10.1 \%$, 60th $6.9 \%$, More than $703.4 \%$

These are exhibited in Fig. 2.

c) Residence (Q9): a. Fuji city $82.8 \%$, b. Fujinomiya city $8.8 \%$, c. Numazu city $2.1 \%$, d. Mishima city $0.7 \%$, e. Shizuoka city $0.9 \%$, F. Else (in Shizuoka Prefecture) $2.1 \%$, g. Outside of Shizuoka Prefecture 2.6\%

These are exhibited in Fig. 3.

d) How often do you come to this shopping street? (Q1)

Everyday $21.2 \%$, More than 1 time a week $17.2 \%$, More than 1 time a month $22.7 \%$,

More than 1 time a year $26.8 \%$, First time $3.0 \%$, Not filled in $4.1 \%$

These are exhibited in Fig. 4.

e) What is the purpose of visiting here? (Q2)

Shopping 17.2\%, Eating and drinking 13.6\%, Business $7.4 \%$, Celebration, event $34.1 \%$,

Leisure, amusement $6.1 \%$, miscellaneous $21.6 \%$

These are exhibited in Fig. 5.

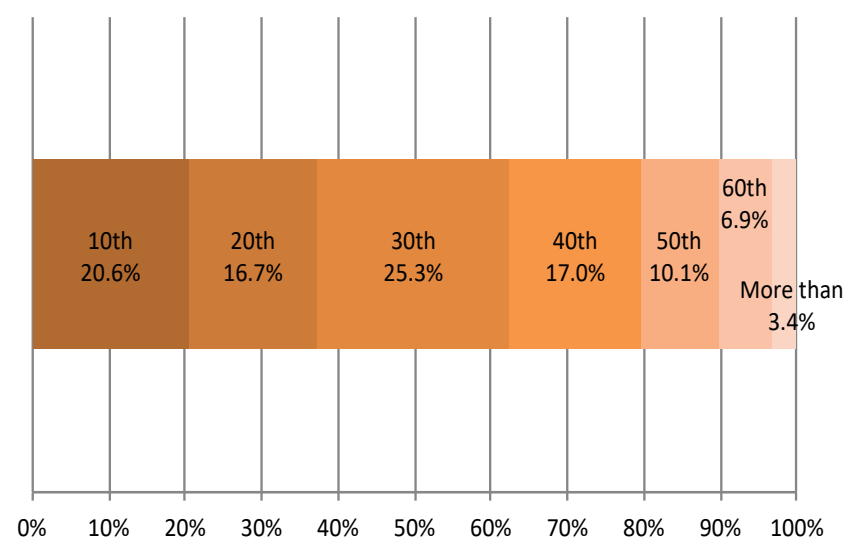

Fig. 2. Age (Q8).

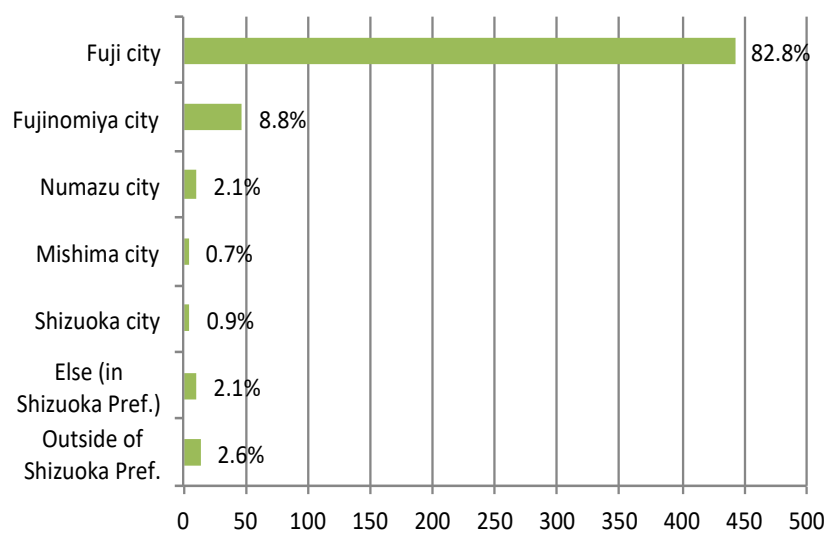

Fig. 3. Residence (Q9).

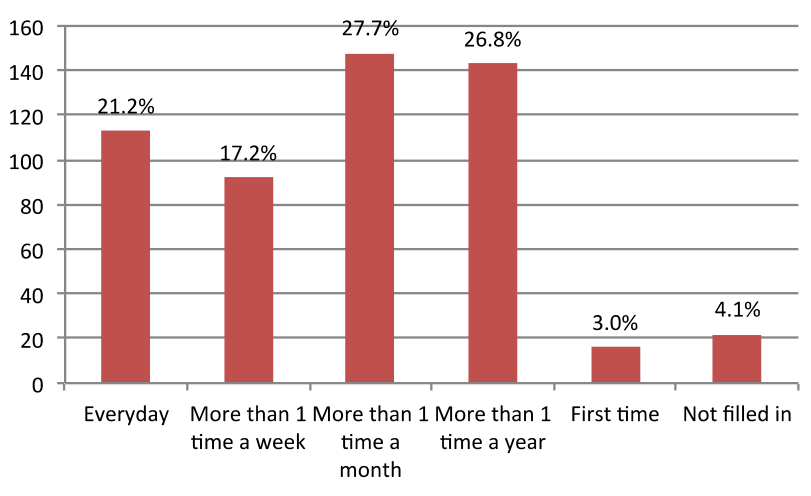

Fig. 4. How often do you Come to this Shopping Street? (Q1).

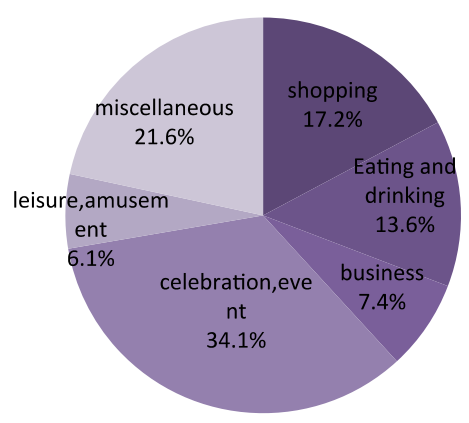

Fig. 5. What is the Purpose of Visiting here? (Q2).

f) How do you feel about the image of the surrounding area at this shopping street? (Q3)

Beautiful $51.2 \%$, Ugly $48.8 \%$, of the united feeling there is $44.3 \%$, Scattered $55.7 \%$,

Varied $38.5 \%$,Featureless $61.5 \%$, New $37.1 \%$, Historic $62.9 \%$, Full of nature $37.1 \%$,Urban $62.9 \%$,

Cheerful 44.1\%, Gloomy 55.9\%, Individualistic $42.0 \%$, Conventional $58.0 \%$, Friendly $57.8 \%$,

Unfriendly $42.2 \%$, Healed $53.3 \%$, Stimulated $46.7 \%$, Open $44.8 \%$, exclusive $55.2 \%$, want to reside $43.6 \%$,

Do not want to reside $56.4 \%$, Warm $55.1 \%$, Aloof $44.9 \%$, Fascinating $42.1 \%$, not fascinating $57.9 \%$,

Want to play $47.1 \%$, Want to examine deliberately $52.9 \%$, lively $36.8 \%$, Calm $63.2 \%$,

Atmosphere of urban $28.0 \%$, Atmosphere of rural area $72.0 \%$

These are exhibited in Fig. 6.

$g$ ) There are many old building at the age of nearly 50 years. Do you think we can still use them? (Q4) $22.1 \%$

Can use it $48.7 \%$, Cannot use it $29.2 \%$, Have no idea

These are exhibited in Fig. 7. 


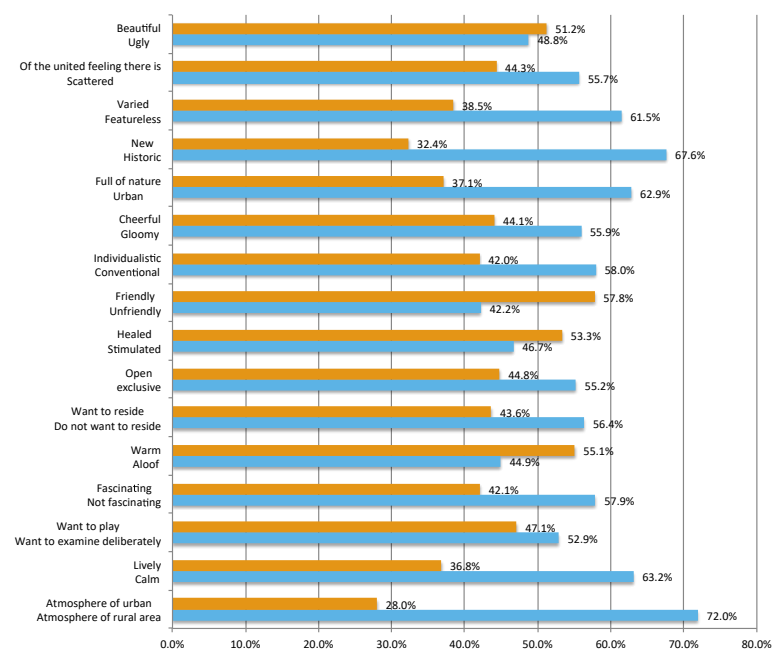

Fig. 6. How do you Feel about the Image of the Surrounding Area at this Shopping Street? (Q3).

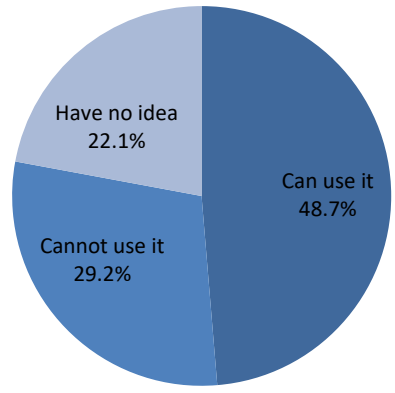

Fig. 7. There are Many Old Building at the Age of Nearly 50 years. Do you think we Can Still use them? (Q4).

$$
\begin{gathered}
\operatorname{Pr}(X=x)=\alpha \lambda(x) \pi(x) \\
\pi(x)=\sum_{u} P(x \mid U=u) \prod_{U_{i}} \pi_{U_{i} X}(u) \\
\lambda(x)=\prod_{Y_{j}} \lambda_{Y_{j} X}(x) \\
\pi_{X Y_{j}}(x)=\pi(x) \prod_{k \neq j} \lambda_{Y_{k} X}(x) \\
\lambda_{X U_{i}}(u)=\sum_{x} \lambda(x) \sum_{k \neq i} P(x \mid U) \prod_{k \neq i} \pi_{U_{k} X}\left(u_{k}\right)
\end{gathered}
$$

\section{BAYESIAN NETWORK ANALYSIS}

In constructing Bayesian Network, it is required to check the causal relationship among groups of items.

BAYONET software (http://www.msi.co.jp/BAYONET/) is used. When plural nodes exist in the same group, it occurs that causal relationship is hard to set a priori. In that case, BAYONET system set the sequence automatically utilizing AIC standard. Node and parameter of Fig. 8 are exhibited in Table I.

In the next section, sensitivity analysis is achieved by back propagation method. Back propagation method is conducted in the following method (Fig. 9).

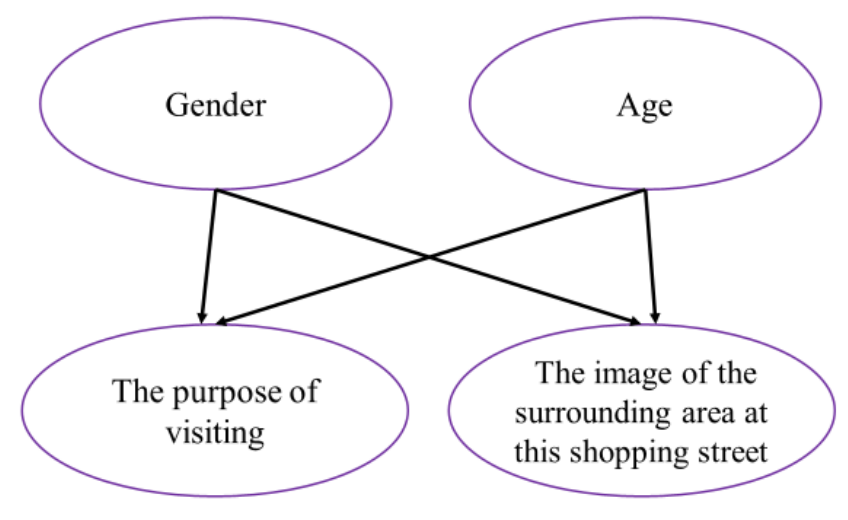

Fig. 8. A Built Model.

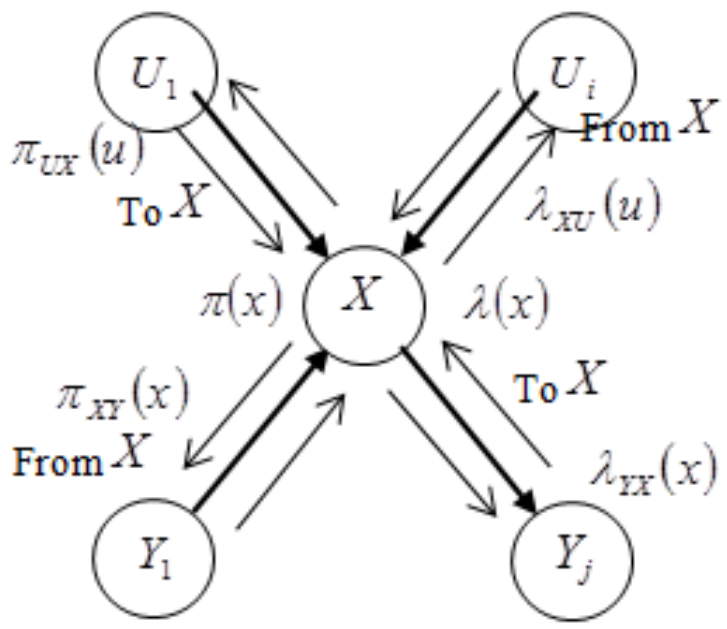

Fig. 9. Back Propagation Method (Takeyasu et al., 2010). 
TABLE I. NODE AND PARAMETER

\begin{tabular}{|c|c|c|c|c|c|c|c|c|c|c|c|c|c|c|}
\hline \multirow{2}{*}{ Node } & \multicolumn{14}{|c|}{ Parameter } \\
\hline & 1 & \multicolumn{2}{|l|}{2} & 3 & & 4 & 5 & \multicolumn{2}{|l|}{6} & \multicolumn{2}{|l|}{7} & 8 & 9 & 10 \\
\hline Gender & Male & \multicolumn{2}{|l|}{ Female } & & & & & & & & & & & \\
\hline Age & 10th & \multicolumn{2}{|l|}{ 20th } & 30th & \multicolumn{2}{|c|}{ 40th } & 50 th & \multicolumn{2}{|l|}{ 60th } & \multicolumn{2}{|c|}{$\begin{array}{l}\text { More } \\
\text { than } 70\end{array}$} & & & \\
\hline The purpose of visiting & $\begin{array}{l}\text { Shopp } \\
\text { ing }\end{array}$ & \multicolumn{2}{|c|}{$\begin{array}{l}\text { Eating and } \\
\text { drinking }\end{array}$} & Business & \multicolumn{2}{|c|}{$\begin{array}{l}\text { Celebration } \\
\text { event }\end{array}$} & $\begin{array}{l}\text { Leisure, } \\
\text { amusem } \\
\text { ent }\end{array}$ & \multicolumn{2}{|c|}{$\begin{array}{l}\text { miscellan } \\
\text { eous }\end{array}$} & & & & & \\
\hline $\begin{array}{l}\text { The image of the surrounding area at } \\
\text { this shopping street }\end{array}$ & $\begin{array}{l}\text { Beauti } \\
\text { ful }\end{array}$ & \multicolumn{2}{|l|}{ Ugly } & $\begin{array}{l}\text { Of the united } \\
\text { feeling there is }\end{array}$ & \multicolumn{2}{|c|}{ Scattered } & Varied & \multicolumn{2}{|c|}{$\begin{array}{l}\text { Featurele } \\
\text { ss }\end{array}$} & \multicolumn{2}{|c|}{ New } & $\begin{array}{l}\text { Histo } \\
\text { ric }\end{array}$ & $\begin{array}{l}\text { Full } \\
\text { of } \\
\text { nat } \\
\text { ure } \\
\end{array}$ & $\begin{array}{l}\text { Urb } \\
\text { an }\end{array}$ \\
\hline \multirow{2}{*}{\multicolumn{2}{|c|}{ Node }} & \\
\hline & & \multicolumn{3}{|c|}{\begin{tabular}{l|l}
\multicolumn{2}{|l}{ Parameter } \\
11 & 12
\end{tabular}} & 14 & 4 & 15 & 16 & 17 & & 18 & 19 & 20 & \\
\hline $\begin{array}{l}\text { The image of the surrounding area at th } \\
\text { shopping street }\end{array}$ & & $\begin{array}{l}\text { Cheerf } \\
\text { ul }\end{array}$ & $\begin{array}{l}\text { Gloom } \\
\mathrm{y}\end{array}$ & $\begin{array}{l}\text { Individualis } \\
\text { tic }\end{array}$ & & $\begin{array}{l}\text { Conventio } \\
\text { ial }\end{array}$ & $\begin{array}{l}\text { Friendl } \\
\mathrm{y}\end{array}$ & $\begin{array}{l}\text { Unfriend } \\
\text { ly }\end{array}$ & \begin{tabular}{|l} 
Heale \\
$\mathrm{d}$
\end{tabular} & & $\begin{array}{l}\text { Stimulat } \\
\text { ed }\end{array}$ & $\begin{array}{l}\mathrm{O}_{1} \\
\mathrm{n}\end{array}$ & $\begin{array}{l}\text { E } \\
\text { ve }\end{array}$ & clusi \\
\hline N & & Parameter & & & & & & & & & & & & \\
\hline Node & & 21 & 22 & & 23 & 24 & 25 & 26 & 27 & & 28 & & 29 & 30 \\
\hline $\begin{array}{l}\text { The image of the surrounding area at thi } \\
\text { shopping street }\end{array}$ & & $\begin{array}{l}\text { Want to } \\
\text { reside }\end{array}$ & $\begin{array}{l}\text { Do no } \\
\text { reside }\end{array}$ & want to & $\begin{array}{l}\text { War } \\
\mathrm{m}\end{array}$ & $\begin{array}{l}\text { Alo } \\
\text { of }\end{array}$ & $\begin{array}{l}\text { Fascinati } \\
\text { ng }\end{array}$ & $\begin{array}{l}\text { Not } \\
\text { fascinati } \\
\text { ng }\end{array}$ & $\begin{array}{l}\text { Want t } \\
\text { play }\end{array}$ & & $\begin{array}{l}\text { Want } \\
\text { exam } \\
\text { delib } \\
\text { ely } \\
\end{array}$ & $\begin{array}{l}\text { t to } \\
\text { nine } \\
\text { perat }\end{array}$ & $\begin{array}{l}\text { Live } \\
\text { ly }\end{array}$ & $\begin{array}{l}\mathrm{Cal} \\
\mathrm{m}\end{array}$ \\
\hline Nod & & & & & & Parameter & & & & & & & & \\
\hline Node & & & & & & 31 & & & 32 & & & & & \\
\hline The image of the surrounding area at th & shoppi & ig street & & & & Atmosphe & ere of urban & & Atmo & osphe & ere of rur & ral area & & \\
\hline
\end{tabular}

\section{SENSITIVITY ANALYSIS}

Now, posterior probability is calculated by setting evidence as, for example, 1.0. Comparing Prior probability and Posterior probability, the change can be seen and the preference or image of the surrounding area at this shopping street can be confirmed. Evidence is set to all parameters. Therefore the analysis volume becomes too large. In this paper, nearly $1 / 3$ of the total cases are picked up and analysis is executed. Nodes that are analyzed here are "Gender", "Age" and "The purpose of visiting". Another paper for the rest of them is prepared.

As stated above, evidence is set to each parameter, and the calculated posterior probability is exhibited in Appendix 2 which includes the calculation results of odds ratio.

Here, each item is classified by the strength of the odds ratio.

- Very Strong (+++): Select major parameter of which the odds ratio is more than 1.6

- Strong (++): Select major parameter of which the odds ratio is more than 1.3

- Medium (+): Select major parameter of which the odds ratio is more than 1.08

- Weak: Else

Now each of them is examined for Very Strong, Strong and Medium case.
A. Sensitivity Analysis for "The Purpose of Visiting"

1) Setting evidence to "Shopping": After setting evidence to "Shopping", the result is exhibited in Table II.

Those who visit for "Shopping" had come with the purpose of visiting for "Leisure, amusement" of an age of " $20^{\text {th }}$," " $60^{\text {th }}$ ", or "More than 70" in which the gender is "Female".

(Very Strong part is indicated by bold character and Strong is indicated by italic.)

2) Setting evidence to "Eating and drinking": After setting evidence to "Eating and drinking", the result is exhibited in Table III.

Those who visit for "Eating and drinking" had come with the purpose of visiting for "Business", "Celebration, event" under the image of the surrounding area at this shopping street as "Scattered", "Conventional" or "Exclusive" of an age of "20th", "40th" or "50th" in which the gender is "Male".

\section{TABLE II. SETTING EVIDENCE TO “ShOPPING” CASE}

\begin{tabular}{|l|l|}
\hline Leisure, amusement & + \\
\hline Female & ++ \\
\hline Age: 20 th & + \\
\hline Age: 60th & + \\
\hline Age: More than 70 & ++ \\
\hline
\end{tabular}


TABLE III. SETting EvidENCE TO “EATING AND DRINKING” CASE

\begin{tabular}{|l|l|}
\hline Business & + \\
\hline Celebration、 event & + \\
\hline Scattered & + \\
\hline Conventional & + \\
\hline Exclusive & + \\
\hline Male & + \\
\hline Age: 20th & ++ \\
\hline Age: 40th & ++ \\
\hline Age: 50th & ++ \\
\hline
\end{tabular}

3) Setting evidence to "Business": After setting evidence to "Business", the result is exhibited in Table IV.

Those who visit for "Business" had come with the purpose of visiting for "Eating and drinking", "Celebration 、 event" under the image of the surrounding area at this shopping street as "Conventional" or "Aloof" of an age of "20th", "30 th" or "50th" in which the gender is "Male".

4) Setting evidence to "Celebration 、 event": After setting evidence to "Celebration 、 event", the result is exhibited in Table V.

Those who visit for "Celebration、 event" had come with the purpose of visiting for "Eating and drinking", "Business" under the image of the surrounding area at this shopping street as "Scattered", "Conventional" or "Exclusive" of an age of "30th", "40th" or "50th" in which the gender is "Male".

TABLE IV. Setting Evidence to "Business" CASE

\begin{tabular}{|c|c|}
\hline Eating and drinking & + \\
\hline Celebration, event & + \\
\hline Conventional & + \\
\hline Aloof & + \\
\hline Male & +++ \\
\hline Age: 20th & +++ \\
\hline Age: 30th & + \\
\hline Age: 50th & ++ \\
\hline
\end{tabular}

TABle V. Setting Evidence to “Celebration、 Event” CASe

\begin{tabular}{|c|c|}
\hline Eating and drinking & + \\
\hline Business & + \\
\hline Scattered & + \\
\hline Conventional & + \\
\hline Exclusive & + \\
\hline Male & ++ \\
\hline Age: 30th & + \\
\hline Age: 40th & + \\
\hline Age: 50th & ++ \\
\hline
\end{tabular}

5) Setting evidence to "Leisure, amusement": After setting evidence to "Leisure, amusement", the result is exhibited in Table VI.

Those who visit for "Leisure, amusement" had come with the purpose of visiting for "Shopping" under the image of the surrounding area at this shopping street as "Unfriendly" of an age of "60th" or "More than 70 "in which the gender is "Female".

\section{B. Sensitivity Analysis for "Gender"}

1) Setting Evidence to "Male": After setting evidence to "Male", the result is exhibited in Table VII.

Those who are "Male" had come with the purpose of visiting for "Eating and drinking", "Business", or "Celebration 、 event" under the image of the surrounding area at this shopping street as "Gloomy", "Conventional" or "Aloof".

2) Setting Evidence to "Female": After setting evidence to "Female", the result is exhibited in Table VIII.

Those who are "Female" had come with the purpose of visiting for "Shopping", or "Leisure, amusement" under the image of the surrounding area at this shopping street as "Beautiful", "New", "Full of nature", "Cheerful", "Individualistic", "Warm" or "Want to play".

TABLE VI. Setting Evidence to "Leisure, Amusement” CASE

\begin{tabular}{|l|l|}
\hline Shopping & + \\
\hline Unfriendly & + \\
\hline Female & ++ \\
\hline Age: 60th & ++ \\
\hline Age: More than 70 & ++ \\
\hline
\end{tabular}

TABLE VII. Setting Evidence to "MALE” CASE

\begin{tabular}{|l|l|}
\hline Eating and drinking & + \\
\hline Business & ++ \\
\hline Celebration、 event & + \\
\hline Gloomy & + \\
\hline Conventional & + \\
\hline Aloof & + \\
\hline
\end{tabular}

TABLE VIII. Setting Evidence to "Female” CASE

\begin{tabular}{|l|l|}
\hline Shopping & + \\
\hline Leisure, amusement & + \\
\hline Beautiful & + \\
\hline New & + \\
\hline Full of nature & + \\
\hline Cheerful & + \\
\hline Individualistic & + \\
\hline Warm & + \\
\hline Want to play & + \\
\hline
\end{tabular}

C. Sensitivity Analysis for "Age"

1) Setting evidence to "10th": After setting evidence to "10th", the result is exhibited in Table IX.

Those who are at the age of "10th" had come under the image of the surrounding area at this shopping street as "Beautiful", "Of the united feeling there is", "Varied", "Full of nature", "Urban", "Cheerful", "Individualistic", "Friendly", 
"Healed", "Open", "Want to reside", "Warm", "Fascinating", "Want to play" or "Lively".

2) Setting evidence to "20th": After setting evidence to "20th", the result is exhibited in Table X.

Those who are at the age of "20th" had come with the purpose of visiting for "Shopping", "Eating and drinking" or "Business" under the image of the surrounding area at this shopping street as "Beautiful", "New", "Full of nature", "Cheerful", "Conventional", "Healed", "Stimulated", "Open", "Want to reside", " Fascinating", "Want to play", "Want to examine deliberately" or "Lively".

TABLE IX. SETting EvidEnCE TO “10TH” CASE

\begin{tabular}{|l|l|}
\hline Beautiful & ++ \\
\hline Of the united feeling there is & ++ \\
\hline Varied & ++ \\
\hline Full of nature & ++ \\
\hline Urban & + \\
\hline Cheerful & ++ \\
\hline Individualistic & +++ \\
\hline Friendly & +++ \\
\hline Healed & ++ \\
\hline Open & +++ \\
\hline Want to reside & ++ \\
\hline Warm & +++ \\
\hline Fascinating & +++ \\
\hline Want to play & +++ \\
\hline Lively & ++ \\
\hline
\end{tabular}

TABLE X. SetTing Evidence TO “20TH” CASE

\begin{tabular}{|l|l|}
\hline Shopping & ++ \\
\hline Eating and drinking & ++ \\
\hline Business & +++ \\
\hline Beautiful & + \\
\hline New & + \\
\hline Full of nature & + \\
\hline Cheerful & ++ \\
\hline Conventional & + \\
\hline Healed & + \\
\hline Stimulated & + \\
\hline Open & + \\
\hline Want to reside & + \\
\hline Fascinating & + \\
\hline Want to play & + \\
\hline Want to examine deliberately & + \\
\hline Lively & + \\
\hline
\end{tabular}

3) Setting evidence to "30th": After setting evidence to "30th", the result is exhibited in Table XI.

Those who are at the age of "30th" had come with the purpose of visiting for "Business" or "Celebration 、 event" under the image of the surrounding area at this shopping street as "Conventional" or "Want to play".
4) Setting evidence to " $40^{\text {th } \text { ": }}$ After setting evidence to " 40 th", the result is exhibited in Table XII.

Those who are at the age of "40th" had come with the purpose of visiting for "Eating and drinking" or "Celebration 、 event" under the image of the surrounding area at this shopping street as "Scattered", "Featureless", "New", "Gloomy", "Exclusive", "Do not want to reside", "Aloof", "Not fascinating", "Calm", "Atmosphere of urban" or "Atmosphere of rural area".

TABLE XI. SetTing EvidencE TO “30TH” CASE

\begin{tabular}{|l|l|}
\hline Business & + \\
\hline Celebration、 event & + \\
\hline Conventional & + \\
\hline Want to play & + \\
\hline
\end{tabular}

TABLE XII. SETting EVIDENCE TO “ $400^{\mathrm{TH}}$ " CASE

\begin{tabular}{|l|l|}
\hline Eating and drinking & ++ \\
\hline Celebration、 event & ++ \\
\hline Scattered & + \\
\hline Featureless & + \\
\hline New & + \\
\hline Gloomy & + \\
\hline Exclusive & ++ \\
\hline Do not want to reside & ++ \\
\hline Aloof & + \\
\hline Not fascinating & + \\
\hline Calm & + \\
\hline Atmosphere of urban & ++ \\
\hline Atmosphere of rural area & + \\
\hline
\end{tabular}

TABLE XIII. Setting Evidence TO “50TH” CASE

\begin{tabular}{|l|l|}
\hline Eating and drinking & ++ \\
\hline Business & ++ \\
\hline Celebration event & +++ \\
\hline Ugly & +++ \\
\hline Scattered & +++ \\
\hline Featureless & + \\
\hline Urban & + \\
\hline Gloomy & ++ \\
\hline Individualistic & + \\
\hline Conventional & + \\
\hline Unfriendly & ++ \\
\hline Stimulated & ++ \\
\hline Exclusive & ++ \\
\hline Aloof & ++ \\
\hline Not fascinating & ++ \\
\hline Calm & + \\
\hline Atmosphere of urban & + \\
\hline Atmosphere of rural area & + \\
\hline
\end{tabular}

5) Setting evidence to "50th": After setting evidence to "50th", the result is exhibited in Table XIII.

Those who are at the age of "50th" had come with the purpose of visiting for "Eating and drinking", "Business" or "Celebration、 event" under the image of the surrounding area at this shopping street as "Ugly", "Scattered", 
"Featureless", "Urban", “Gloomy", "Individualistic", "Conventional", "Unfriendly", "Stimulated", "Exclusive", "Aloof", "Not fascinating", "Calm", "Atmosphere of urban" or "Atmosphere of rural area".

6) Setting evidence to "60th": After setting evidence to "60th", the result is exhibited in Table XIV.

Those who are at the age of "60th" had come with the purpose of visiting for "Shopping", "Leisure, amusement" under the image of the surrounding area at this shopping street as "Scattered", "Featureless", "New", "Urban", "Gloomy", "Conventional", "Unfriendly", "Stimulated", "Exclusive”, "Do not want to reside", "Aloof", " Not fascinating", "Want to examine deliberately", "Calm" or "Atmosphere of rural area".

7) Setting evidence to "More than 70": After setting evidence to "More than 70", the result is exhibited in Table XV.

Those who are at the age of "More than 70" had come with the purpose of visiting for "Shopping", "Celebration、 event" or "Leisure, amusement" under the image of the surrounding area at this shopping street as "Ugly", "Featureless", "Historic", "Full of nature", "Gloomy", "Conventional", "Unfriendly", "Stimulated", "Exclusive", "Do not want to reside", "Aloof", "Not fascinating", "Want to examine deliberately", "Calm" or "Atmosphere of rural area".

TABLE XIV. SetTING EvidENCE TO “60TH” CASE

\begin{tabular}{|l|l|}
\hline Shopping & + \\
\hline Leisure, amusement & +++ \\
\hline Scattered & +++ \\
\hline Featureless & +++ \\
\hline New & + \\
\hline Urban & +++ \\
\hline Gloomy & +++ \\
\hline Conventional & ++ \\
\hline Unfriendly & +++ \\
\hline Stimulated & +++ \\
\hline Exclusive & ++ \\
\hline Do not want to reside & +++ \\
\hline Aloof & + \\
\hline Not fascinating & ++ \\
\hline Want to examine deliberately & +++ \\
\hline Calm & +++ \\
\hline Atmosphere of rural area & +++ \\
\hline
\end{tabular}

TABLE XV. Setting Evidence to “More than 70" CASE

\begin{tabular}{|l|l|}
\hline Shopping & +++ \\
\hline Celebration、 event & + \\
\hline Leisure, amusement & +++ \\
\hline Ugly & + \\
\hline Featureless & + \\
\hline Historic & ++ \\
\hline Full of nature & + \\
\hline Gloomy & +++ \\
\hline Conventional & + \\
\hline Unfriendly & +++ \\
\hline Stimulated & +++ \\
\hline Exclusive & +++ \\
\hline Do not want to reside & ++ \\
\hline Aloof & +++ \\
\hline Not fascinating & + \\
\hline Want to examine deliberately & ++ \\
\hline Calm & +++ \\
\hline Atmosphere of rural area & + \\
\hline
\end{tabular}

\section{CONCLUSION}

Shopping streets at local city in Japan became old and are generally declining. In this paper, the area rebirth and/or regional revitalization of shopping street are handled. Fuji city in Japan is focused. Four big festivals are held at Fuji city (two for Fuji Shopping Street Town and two for Yoshiwara Shopping Street Town). Many people visit these festivals including residents in that area. There is a big difference between Fuji Shopping Street Town and Yoshiwara Shopping Street Town. Therefore Fuji Shopping Street Town is focused in this paper. A questionnaire investigation to the residents and visitors is conducted during these periods in order to clarify residents and visitors' needs for the shopping street, and utilize them to the plan building of the area rebirth and/or regional revitalization of shopping street. These are analyzed by using Bayesian Network. By that model, the causal relationship is sequentially chained by the characteristics of visitors, the purpose of visiting and the image of the surrounding area at this shopping street. This is really a quite new approach in this field and there is no related paper on this theme as far as searched.

In the Bayesian Network Analysis, model was built under the examination of the causal relationship among items. These are analyzed by sensitivity analysis and odds ratio is calculated to the results of sensitivity analysis in order to obtain much clearer results. The main result of sensitivity analysis is as follows. 
Those who visit for "Business" had come with the purpose of visiting for "Eating and drinking", "Celebration v event" under the image of the surrounding area at this shopping street as "Conventional" or "Aloof" of an age of "20th", "30th" or "50th" in which the gender is "Male".

Those who are "Male" had come with the purpose of visiting for "Eating and drinking", "Business", or "Celebration 、 event" under the image of the surrounding area at this shopping street as "Gloomy", "Conventional" or "Aloof".

Those who are at the age of "10th" had come under the image of the surrounding area at this shopping street as "Beautiful", "Of the united feeling there is", "Varied", "Full of nature", "Urban", "Cheerful", "Individualistic", "Friendly", "Healed", "Open", "Want to reside", "Warm", "Fascinating", "Want to play" or "Lively".

Those who are at the age of "50th" had come with the purpose of visiting for "Eating and drinking", "Business" or "Celebration、 event" under the image of the surrounding area at this shopping street as "Ugly", "Scattered", "Featureless", "Urban", "Gloomy", "Individualistic", "Conventional", "Unfriendly", "Stimulated", "Exclusive", "Aloof”, "Not fascinating", "Calm", "Atmosphere of urban" or "Atmosphere of rural area".

Those who are at the age of "More than 70" had come with the purpose of visiting for "Shopping", "Celebration、 event" or "Leisure, amusement" under the image of the surrounding area at this shopping street as "Ugly", "Featureless", "Historic", "Full of nature", "Gloomy", "Conventional", "Unfriendly", "Stimulated", "Exclusive", "Do not want to reside", "Aloof", "Not fascinating", "Want to examine deliberately", "Calm" or "Atmosphere of rural area".
The analysis utilizing Bayesian Network enabled us to visualize the causal relationship among items. Furthermore, sensitivity analysis brought us estimating and predicting the prospective visitors. Sensitivity analysis was achieved by back propagation method. These are utilized for constructing a much more effective and useful plan building.

Although it has a limitation that it is restricted in the number of researches, the fruitful results could be obtained. To confirm the findings by utilizing the new consecutive visiting records would be the future works to be investigated.

\section{ACKNOWLEDGMENTS}

The authors are grateful to all those who supported us for answering the questionnaire investigation.

\section{REFERENCES}

[1] Inoue, Akiko(2017) "Changes in Local Communities Brought by Municipal Mergers : From the Viewpoint of Tourism Promotion as the Main Industry", Bulletin of the Faculty of Regional Development Studies, Otemon Gakuin University, Vol.2, pp.1-32.

[2] Ingu, Shuzo / Uemura, Miki / Uchida, Yuka / Omiya, Misa / Miura, Taiki / Hironori, Hironori(2017)"A study on the application of geothermal power generation to local revitalization in Obama Town, Unzen City: in consideration of futurability in Obama", Environmental Science Research, Nagasaki University, 20(1), pp.51-63.

[3] Ohkubo, Yukio(2017) "Current status and problems in Jigenji-dori shopping area : from a consumer questionnaire", Bulletin of Local Research, Kagoshima International University, Vol.44 no.2 p.1 -15.

[4] Yoshida, Ituki (2009) "Consideration on the Characteristic of Visitors' Activity and the Research Method for Tourist Visitors in Urban Areas"

[5] Doi, Hideji(2009) "Evaluation of policies to build tourist destinations and statistical analysis" Nippon Hyoron Sha

[6] Kano, Michiko (2011) " Characteristic analysis of Atami tourists: Reconsideration based on data add and modify" Shizuoka Economic Research. 16 (2), p. 61-78, Shizuoka University

[7] Takeyasu, Kazuhiro et al.(2010) "Modern Marketing", Chuoukeizaisha Publishing

APPENDIX 1

Questionnaire Sheet about the Image around the Shopping Street

1. How often do you come to this shopping street?

a. Everyday b. ( ) times a week c. ( ) times a month d. ( ) times a year

e. miscellaneous (

)

2. What is the purpose of visiting here? (Plural answers allowed)

a. shopping b. eating and drinking $\mathrm{c}$. business d. celebration vevent e. leisure, amusement

f. miscellaneous (

)

3. How do you feel about the image of the surrounding area at this shopping street?

Select the position

\begin{tabular}{|c|c|c|c|c|c|c|}
\hline Beautiful & . & $\cdot$ & $\cdot$ & $\cdot$ & $\cdot$ & Ugly \\
\hline Of the united feeling there is & - & $\cdot$ & $\cdot$ & $\cdot$ & $\cdot$ & Scattered \\
\hline Varied & . & . & . & . & . & Featureless \\
\hline New & $\cdot$ & $\cdot$ & $\cdot$ & $\cdot$ & $\cdot$ & Historic \\
\hline Full of nature & $\cdot$ & $\cdot$ & $\cdot$ & $\cdot$ & $\cdot$ & Urban \\
\hline Cheerful & $\cdot$ & $\cdot$ & $\cdot$ & $\cdot$ & $\cdot$ & Gloomy \\
\hline Individualistic & $\cdot$ & $\cdot$ & $\cdot$ & $\cdot$ & $\cdot$ & Conventional \\
\hline Friendly & $\cdot$ & $\cdot$ & $\cdot$ & $\cdot$ & $\cdot$ & Unfriendly \\
\hline Healed & $\cdot$ & $\cdot$ & $\cdot$ & $\cdot$ & $\cdot$ & Stimulated \\
\hline Open & $\cdot$ & $\cdot$ & $\cdot$ & $\cdot$ & $\cdot$ & exclusive \\
\hline
\end{tabular}




\begin{tabular}{|c|c|c|c|c|c|c|}
\hline Want to reside & - & $\cdot$ & . & . & $\cdot$ & Do not want to reside \\
\hline Warm & . & . & . & . & . & Aloof \\
\hline Fascinating & - & $\cdot$ & . & . & $\cdot$ & Not fascinating \\
\hline Want to play & $\cdot$ & $\cdot$ & $\cdot$ & $\cdot$ & $\cdot$ & Want to examine deliberately \\
\hline Lively & . & $\cdot$ & . & . & . & Calm \\
\hline Atmosphere of urban & - & $\cdot$ & . & . & $\cdot$ & Atmosphere of rural area \\
\hline
\end{tabular}

4. There are many old building at the age of nearly 50 years. Do you think we can still use them?

a. Can use it b. Cannot use it c. Have no idea

5. Is there any functions or facilities that will be useful?

6. Comments

7. Sex

a. Male b. Female

8. Age

a.10th b.20th c.30th d.40th e.50th f.60th g. More than70

9. Residence

a. Fuji City b. Fujinomiya City c. Numazu City d. Mishima City e. Shizuoka City f. Miscellaneous in Shizuoka Prefecture

g. Outside of Shizuoka Prefecture [ 
APPENDIX 2

Calculated posterior probability

\begin{tabular}{|c|c|c|c|c|c|c|c|c|c|c|c|c|}
\hline \multirow[b]{2}{*}{ name_fuji } & \multirow[b]{2}{*}{ state } & \multirow[b]{2}{*}{ Prior } & \multicolumn{2}{|c|}{ The purpose of visiting } & \multirow[b]{2}{*}{\begin{tabular}{|l} 
Eating and \\
drinking
\end{tabular}} & \multirow[b]{2}{*}{\begin{tabular}{|l} 
Eating and \\
drinking_odds
\end{tabular}} & \multirow[b]{2}{*}{ Business } & \multirow[b]{2}{*}{ Business_odds } & \multirow[b]{2}{*}{\begin{tabular}{|l}
$\begin{array}{l}\text { Celebration, } \\
\text { event }\end{array}$ \\
\end{tabular}} & \multirow[b]{2}{*}{$\begin{array}{l}\begin{array}{l}\text { Celebration, } \\
\text { event_odds }\end{array} \\
\end{array}$} & \multirow[b]{2}{*}{\begin{tabular}{|l|}
$\begin{array}{l}\text { Leisure, } \\
\text { amusement }\end{array}$ \\
\end{tabular}} & \multirow[b]{2}{*}{$\begin{array}{l}\begin{array}{l}\text { Leisure, } \\
\text { amusement_odds }\end{array} \\
\end{array}$} \\
\hline & & & Shopping & Shopping_odds & & & & & & & & \\
\hline \multirow{5}{*}{$\begin{array}{l}\text { The purpose of } \\
\text { visiting }\end{array}$} & Shopping & 0.215 & 1 & - & 0.211 & 0.976 & 0.208 & 0.964 & 0.211 & 0.981 & 0.233 & 1.114 \\
\hline & Eating and drinking & 0.174 & 0.172 & 0.988 & 1 & - & 0.197 & 1.163 & 0.191 & 1.121 & 0.155 & 0.867 \\
\hline & Business & 0.103 & 0.101 & 0.985 & 0.117 & 1.164 & & - & 0.113 & 1.115 & 0.090 & 0.866 \\
\hline & Celebration, event & 0.396 & 0.392 & 0.983 & 0.433 & 1.167 & 0.435 & 1.177 & 1 & - & 0.374 & 0.913 \\
\hline & Leisure, amusement & 0.089 & 0.098 & 1.111 & 0.080 & 0.890 & 0.079 & 0.878 & 0.084 & 0.945 & & - \\
\hline \multirow{32}{*}{$\begin{array}{l}\text { The image of } \\
\text { the surrounding } \\
\text { area at this } \\
\text { shopping street }\end{array}$} & Beautiful & 0.339 & 0.342 & 1.013 & 0.324 & 0.933 & 0.328 & 0.949 & 0.326 & 0.942 & 0.346 & 1.028 \\
\hline & Ugly & 0.292 & 0.287 & 0.977 & 0.299 & 1.036 & 0.299 & 1.033 & 0.300 & 1.039 & 0.285 & 0.969 \\
\hline & $\begin{array}{l}\text { Of the united feeling } \\
\text { there is }\end{array}$ & 0.255 & 0.251 & 0.983 & 0.239 & 0.919 & 0.241 & 0.926 & 0.240 & 0.926 & 0.253 & 0.989 \\
\hline & Scattered & 0.381 & 0.381 & 1.000 & 0.399 & 1.081 & 0.392 & 1.048 & 0.400 & 1.084 & 0.390 & 1.039 \\
\hline & Varied & 0.175 & 0.171 & 0.968 & 0.167 & 0.943 & 0.167 & 0.944 & 0.168 & 0.952 & 0.171 & 0.969 \\
\hline & Featureless & 0.490 & 0.491 & 1.004 & 0.491 & 1.008 & 0.487 & 0.990 & 0.496 & 1.025 & 0.503 & 1.056 \\
\hline & New & 0.124 & 0.128 & 1.039 & 0.129 & 1.047 & 0.124 & 1.002 & 0.127 & 1.026 & 0.128 & 1.036 \\
\hline & Historic & 0.561 & 0.565 & 1.014 & 0.557 & 0.983 & 0.556 & 0.980 & 0.559 & 0.992 & 0.570 & 1.038 \\
\hline & Full of nature & 0.370 & 0.374 & 1.017 & 0.350 & 0.919 & 0.358 & 0.950 & 0.355 & 0.936 & 0.381 & 1.046 \\
\hline & Urban & 0.231 & 0.228 & 0.983 & 0.225 & 0.963 & 0.223 & 0.955 & 0.228 & 0.982 & 0.235 & 1.022 \\
\hline & Cheerful & 0.259 & 0.259 & 1.002 & 0.251 & 0.959 & 0.249 & 0.952 & 0.244 & 0.925 & 0.249 & 0.950 \\
\hline & Gloomy & 0.432 & 0.434 & 1.008 & 0.444 & 1.053 & 0.445 & 1.057 & 0.447 & 1.064 & 0.435 & 1.015 \\
\hline & Individualistic & 0.238 & 0.232 & 0.964 & 0.214 & 0.869 & 0.213 & 0.866 & 0.218 & 0.891 & 0.237 & 0.994 \\
\hline & Conventional & 0.438 & 0.440 & 1.005 & 0.471 & 1.143 & 0.479 & 1.177 & 0.466 & 1.120 & 0.432 & 0.975 \\
\hline & Friendly & 0.443 & 0.434 & 0.966 & 0.413 & 0.883 & 0.416 & 0.897 & 0.417 & 0.900 & 0.435 & 0.967 \\
\hline & Unfriendly & 0.236 & 0.245 & 1.047 & 0.242 & 1.032 & 0.242 & 1.030 & 0.246 & 1.053 & 0.257 & 1.122 \\
\hline & Healed & 0.285 & 0.279 & 0.969 & 0.279 & 0.970 & 0.282 & 0.986 & 0.275 & 0.953 & 0.267 & 0.913 \\
\hline & Stimulated & 0.180 & 0.187 & 1.050 & 0.182 & 1.016 & 0.185 & 1.036 & 0.183 & 1.022 & 0.193 & 1.091 \\
\hline & Open & 0.257 & 0.254 & 0.984 & 0.236 & 0.894 & 0.239 & 0.911 & 0.237 & 0.900 & 0.256 & 0.995 \\
\hline & Exclusive & 0.393 & 0.407 & 1.060 & 0.413 & 1.087 & 0.404 & 1.048 & 0.411 & 1.080 & 0.407 & 1.061 \\
\hline & Want to reside & 0.241 & 0.243 & 1.009 & 0.230 & 0.939 & 0.231 & 0.946 & 0.230 & 0.942 & 0.246 & 1.026 \\
\hline & Do not want to reside & 0.395 & 0.397 & 1.010 & 0.396 & 1.007 & 0.392 & 0.987 & 0.400 & 1.022 & 0.406 & 1.049 \\
\hline & Warm & 0.398 & 0.393 & 0.980 & 0.375 & 0.907 & 0.370 & 0.889 & 0.375 & 0.907 & 0.395 & 0.988 \\
\hline & Aloof & 0.252 & 0.254 & 1.011 & 0.264 & 1.067 & 0.269 & 1.093 & 0.265 & 1.072 & 0.251 & 0.995 \\
\hline & Fascinating & 0.223 & 0.222 & 0.994 & 0.205 & 0.900 & 0.210 & 0.928 & 0.208 & 0.912 & 0.223 & 0.999 \\
\hline & Not fascinating & 0.423 & 0.424 & 1.004 & 0.435 & 1.050 & 0.430 & 1.029 & 0.436 & 1.053 & 0.428 & 1.019 \\
\hline & Want to play & 0.218 & 0.217 & 0.996 & 0.202 & 0.908 & 0.198 & 0.886 & 0.200 & 0.898 & 0.216 & 0.991 \\
\hline & $\begin{array}{l}\begin{array}{l}\text { Want to examine } \\
\text { deliberately }\end{array} \\
\end{array}$ & 0.312 & 0.321 & 1.042 & 0.314 & 1.009 & 0.312 & 0.999 & 0.313 & 1.002 & 0.330 & 1.086 \\
\hline & Lively & 0.181 & 0.178 & 0.982 & 0.175 & 0.960 & 0.176 & 0.967 & 0.173 & 0.948 & 0.174 & 0.949 \\
\hline & Calm & 0.520 & 0.530 & 1.041 & 0.528 & 1.035 & 0.527 & 1.030 & 0.528 & 1.035 & 0.538 & 1.076 \\
\hline & Atmosphere of urban & 0.097 & 0.095 & 0.981 & 0.099 & 1.031 & 0.097 & 1.003 & 0.099 & 1.022 & 0.090 & 0.928 \\
\hline & $\begin{array}{l}\text { Atmosphere of rural } \\
\text { area }\end{array}$ & 0.629 & 0.630 & 1.004 & 0.633 & 1.017 & 0.626 & 0.988 & 0.635 & 1.028 & 0.643 & 1.061 \\
\hline \multirow{2}{*}{ Gender } & Male & 0.433 & 0.364 & 0.751 & 0.485 & 1.235 & 0.556 & 1.642 & 0.492 & 1.267 & 0.285 & 0.522 \\
\hline & Female & 0.567 & 0.636 & 1.331 & 0.515 & 0.810 & 0.444 & 0.609 & 0.508 & 0.789 & 0.715 & 1.916 \\
\hline \multirow{7}{*}{ Age } & 10th & 0.205 & 0.172 & 0.804 & 0.082 & 0.348 & 0.088 & 0.373 & 0.111 & 0.484 & 0.197 & 0.948 \\
\hline & 20th & 0.166 & 0.203 & 1.279 & 0.219 & 1.406 & 0.256 & 1.727 & 0.169 & 1.018 & 0.124 & 0.708 \\
\hline & 30th & 0.251 & 0.229 & 0.886 & 0.263 & 1.064 & 0.286 & 1.191 & 0.277 & 1.143 & 0.261 & 1.051 \\
\hline & 40th & 0.170 & 0.168 & 0.984 & 0.225 & 1.414 & 0.139 & 0.786 & 0.203 & 1.246 & 0.143 & 0.813 \\
\hline & 50th & 0.102 & 0.081 & 0.775 & 0.140 & 1.443 & 0.146 & 1.515 & 0.136 & 1.396 & 0.058 & 0.542 \\
\hline & 60th & 0.070 & 0.079 & 1.129 & 0.051 & 0.712 & 0.053 & 0.735 & 0.066 & 0.933 & 0.133 & 2.025 \\
\hline & More than70 & 0.035 & 0.069 & 2.023 & 0.019 & 0.535 & 0.032 & 0.920 & 0.037 & 1.061 & 0.086 & 2.571 \\
\hline
\end{tabular}




\begin{tabular}{|c|c|c|c|c|c|c|c|c|c|c|c|c|c|}
\hline \multicolumn{14}{|c|}{ The image of the surrounding area at this shopping street } \\
\hline Beautiful & Beautiful_odds & Ugly & Ugly_odds & $\begin{array}{l}\text { Of the united } \\
\text { feeling there is }\end{array}$ & \begin{tabular}{|l|}
$\begin{array}{l}\text { Of the united feeling } \\
\text { there is_odds }\end{array}$ \\
\end{tabular} & Scattered & Scattered_odds & Varied & Varied_odds & Featureless & Featureless_odds & New & New_odds \\
\hline 0.216 & 1.009 & 0.211 & 0.977 & 0.212 & 0.987 & 0.214 & 0.996 & 0.209 & 0.968 & 0.215 & 1.002 & 0.222 & 1.047 \\
\hline 0.167 & 0.950 & 0.178 & 1.029 & 0.163 & 0.928 & 0.183 & 1.060 & 0.166 & 0.946 & 0.175 & 1.005 & 0.181 & 1.047 \\
\hline 0.099 & 0.965 & 0.105 & 1.025 & 0.096 & 0.932 & 0.106 & 1.035 & 0.098 & 0.955 & 0.102 & 0.995 & 0.103 & 1.006 \\
\hline 0.380 & 0.937 & 0.407 & 1.046 & 0.374 & 0.912 & 0.416 & 1.088 & 0.381 & 0.939 & 0.401 & 1.022 & 0.404 & 1.035 \\
\hline 0.091 & 1.029 & 0.086 & 0.965 & 0.088 & 0.991 & 0.090 & 1.015 & 0.087 & 0.977 & 0.091 & 1.029 & 0.092 & 1.041 \\
\hline 1 & - & 0 & 0.000 & 0.347 & 1.036 & 0.328 & 0.952 & 0.347 & 1.036 & 0.336 & 0.983 & 0.336 & 0.984 \\
\hline 0.000 & 0.000 & 1 & - & 0.288 & 0.979 & 0.301 & 1.042 & 0.293 & 1.007 & 0.294 & 1.012 & 0.288 & 0.984 \\
\hline 0.260 & 1.030 & 0.251 & 0.980 & 1 & - & 0 & 0.000 & 0.264 & 1.047 & 0.250 & 0.978 & 0.248 & 0.964 \\
\hline 0.368 & 0.949 & 0.392 & 1.049 & 0 & 0.000 & & - & 0.368 & 0.947 & 0.392 & 1.049 & 0.389 & 1.036 \\
\hline 0.179 & 1.029 & 0.176 & 1.006 & 0.181 & 1.042 & 0.169 & 0.960 & & - & 0 & 0.000 & 0.170 & 0.961 \\
\hline 0.484 & 0.977 & 0.494 & 1.017 & 0.481 & 0.967 & 0.504 & 1.059 & 0 & 0.000 & & - & 0.493 & 1.015 \\
\hline 0.123 & 0.990 & 0.122 & 0.987 & 0.120 & 0.969 & 0.127 & 1.025 & 0.120 & 0.964 & 0.125 & 1.009 & & - \\
\hline 0.564 & 1.010 & 0.563 & 1.008 & 0.562 & 1.001 & 0.560 & 0.994 & 0.564 & 1.009 & 0.561 & 0.998 & 0 & 0.000 \\
\hline 0.380 & 1.046 & 0.367 & 0.987 & 0.379 & 1.038 & 0.359 & 0.954 & 0.379 & 1.039 & 0.367 & 0.985 & 0.364 & 0.976 \\
\hline 0.231 & 1.001 & 0.233 & 1.011 & 0.233 & 1.011 & 0.235 & 1.020 & 0.233 & 1.010 & 0.234 & 1.016 & 0.227 & 0.977 \\
\hline 0.268 & 1.049 & 0.252 & 0.968 & 0.273 & 1.076 & 0.241 & 0.909 & 0.269 & 1.053 & 0.250 & 0.956 & 0.256 & 0.985 \\
\hline 0.421 & 0.956 & 0.438 & 1.024 & 0.419 & 0.950 & 0.448 & 1.069 & 0.420 & 0.952 & 0.439 & 1.030 & 0.435 & 1.014 \\
\hline 0.247 & 1.047 & 0.240 & 1.012 & 0.255 & 1.096 & 0.226 & 0.935 & 0.254 & 1.087 & 0.235 & 0.980 & 0.226 & 0.935 \\
\hline 0.426 & 0.952 & 0.445 & 1.028 & 0.416 & 0.912 & 0.458 & 1.084 & 0.422 & 0.937 & 0.444 & 1.025 & 0.447 & 1.034 \\
\hline 0.456 & 1.057 & 0.439 & 0.986 & 0.465 & 1.093 & 0.421 & 0.914 & 0.464 & 1.087 & 0.435 & 0.967 & 0.427 & 0.938 \\
\hline 0.230 & 0.968 & 0.241 & 1.029 & 0.225 & 0.938 & 0.252 & 1.089 & 0.226 & 0.946 & 0.244 & 1.044 & 0.242 & 1.035 \\
\hline 0.291 & 1.031 & 0.283 & 0.992 & 0.295 & 1.052 & 0.271 & 0.934 & 0.295 & 1.051 & 0.278 & 0.966 & 0.277 & 0.962 \\
\hline 0.178 & 0.986 & 0.183 & 1.021 & 0.176 & 0.976 & 0.188 & 1.053 & 0.174 & 0.964 & 0.184 & 1.027 & 0.182 & 1.015 \\
\hline 0.266 & 1.051 & 0.247 & 0.948 & 0.273 & 1.090 & 0.238 & 0.903 & 0.268 & 1.059 & 0.250 & 0.964 & 0.248 & 0.957 \\
\hline 0.381 & 0.953 & 0.401 & 1.033 & 0.377 & 0.934 & 0.412 & 1.086 & 0.376 & 0.932 & 0.400 & 1.033 & 0.406 & 1.056 \\
\hline 0.246 & 1.029 & 0.239 & 0.987 & 0.250 & 1.052 & 0.233 & 0.958 & 0.247 & 1.031 & 0.239 & 0.986 & 0.237 & 0.978 \\
\hline 0.388 & 0.973 & 0.395 & 1.001 & 0.390 & 0.982 & 0.405 & 1.043 & 0.387 & 0.968 & 0.401 & 1.025 & 0.398 & 1.012 \\
\hline 0.409 & 1.049 & 0.393 & 0.978 & 0.416 & 1.080 & 0.381 & 0.932 & 0.413 & 1.066 & 0.392 & 0.975 & 0.391 & 0.972 \\
\hline 0.244 & 0.956 & 0.259 & 1.040 & 0.243 & 0.951 & 0.263 & 1.062 & 0.244 & 0.957 & 0.256 & 1.023 & 0.253 & 1.008 \\
\hline 0.232 & 1.052 & 0.217 & 0.965 & 0.237 & 1.081 & 0.207 & 0.910 & 0.233 & 1.060 & 0.217 & 0.966 & 0.216 & 0.958 \\
\hline 0.415 & 0.966 & 0.429 & 1.026 & 0.413 & 0.958 & 0.438 & 1.061 & 0.415 & 0.966 & 0.429 & 1.025 & 0.427 & 1.017 \\
\hline 0.228 & 1.064 & 0.207 & 0.941 & 0.233 & 1.090 & 0.198 & 0.888 & 0.229 & 1.068 & 0.210 & 0.953 & 0.215 & 0.985 \\
\hline 0.310 & 0.991 & 0.310 & 0.991 & 0.310 & 0.987 & 0.318 & 1.025 & 0.306 & 0.970 & 0.316 & 1.015 & 0.317 & 1.024 \\
\hline 0.186 & 1.036 & 0.179 & 0.983 & 0.188 & 1.048 & 0.172 & 0.939 & 0.188 & 1.044 & 0.177 & 0.971 & 0.177 & 0.974 \\
\hline 0.514 & 0.976 & 0.521 & 1.006 & 0.511 & 0.965 & 0.533 & 1.056 & 0.508 & 0.954 & 0.526 & 1.027 & 0.527 & 1.031 \\
\hline 0.095 & 0.984 & 0.099 & 1.023 & 0.097 & 0.999 & 0.097 & 1.004 & 0.097 & 1.005 & 0.096 & 0.995 & 0.097 & 1.004 \\
\hline 0.623 & 0.977 & 0.631 & 1.011 & 0.622 & 0.971 & 0.641 & 1.054 & 0.623 & 0.973 & 0.635 & 1.028 & 0.633 & 1.018 \\
\hline 0.390 & 0.837 & 0.444 & 1.047 & 0.425 & 0.969 & 0.442 & 1.036 & 0.416 & 0.935 & 0.431 & 0.993 & 0.380 & 0.804 \\
\hline 0.610 & 1.195 & 0.556 & 0.955 & 0.575 & 1.032 & 0.558 & 0.965 & 0.584 & 1.070 & 0.569 & 1.007 & 0.620 & 1.243 \\
\hline 0.244 & 1.248 & 0.195 & 0.939 & 0.292 & 1.597 & 0.137 & 0.613 & 0.273 & 1.454 & 0.185 & 0.878 & 0.141 & 0.635 \\
\hline 0.177 & 1.079 & 0.136 & 0.788 & 0.168 & 1.014 & 0.133 & 0.770 & 0.148 & 0.873 & 0.142 & 0.833 & 0.189 & 1.167 \\
\hline 0.263 & 1.060 & 0.240 & 0.941 & 0.216 & 0.819 & 0.247 & 0.977 & 0.258 & 1.036 & 0.248 & 0.980 & 0.253 & 1.011 \\
\hline 0.130 & 0.728 & 0.174 & 1.027 & 0.159 & 0.922 & 0.198 & 1.204 & 0.140 & 0.793 & 0.179 & 1.065 & 0.212 & 1.315 \\
\hline 0.089 & 0.864 & 0.160 & 1.685 & 0.079 & 0.755 & 0.146 & 1.508 & 0.108 & 1.068 & 0.115 & 1.143 & 0.089 & 0.864 \\
\hline 0.063 & 0.893 & 0.056 & 0.785 & 0.056 & 0.787 & 0.103 & 1.515 & 0.048 & 0.669 & 0.093 & 1.364 & 0.080 & 1.158 \\
\hline 0.034 & 0.982 & 0.039 & 1.111 & 0.030 & 0.859 & 0.037 & 1.049 & 0.025 & 0.698 & 0.038 & 1.092 & 0.035 & 0.999 \\
\hline
\end{tabular}




\begin{tabular}{|c|c|c|c|c|c|c|c|c|c|c|c|c|c|}
\hline Historic & Historic_odds & Full of nature & \begin{tabular}{|l|}
$\begin{array}{l}\text { Full of } \\
\text { nature_odds }\end{array}$ \\
\end{tabular} & Urban & Urban_odds & Cheerful & Cheerful_odds & Gloomy & Gloomy_odds & Individualistic & Individualistic_odds & Conventional & Conventional_odds \\
\hline 0.216 & 1.007 & 0.217 & 1.014 & 0.211 & 0.982 & 0.214 & 0.998 & 0.215 & 1.002 & 0.208 & 0.961 & 0.214 & 0.997 \\
\hline 0.173 & 0.990 & 0.166 & 0.942 & 0.169 & 0.963 & 0.169 & 0.966 & 0.180 & 1.039 & 0.157 & 0.884 & 0.187 & 1.091 \\
\hline 0.102 & 0.991 & 0.099 & 0.966 & 0.099 & 0.964 & 0.099 & 0.961 & 0.106 & 1.042 & 0.092 & 0.888 & 0.112 & 1.104 \\
\hline 0.394 & 0.995 & 0.380 & 0.935 & 0.390 & 0.975 & 0.372 & 0.906 & 0.410 & 1.062 & 0.364 & 0.873 & 0.421 & 1.109 \\
\hline 0.090 & 1.014 & 0.092 & 1.039 & 0.090 & 1.018 & 0.085 & 0.959 & 0.089 & 1.005 & 0.088 & 0.993 & 0.087 & 0.979 \\
\hline 0.341 & 1.006 & 0.349 & 1.044 & 0.339 & 0.999 & 0.352 & 1.056 & 0.331 & 0.963 & 0.352 & 1.058 & 0.330 & 0.959 \\
\hline 0.293 & 1.005 & 0.290 & 0.989 & 0.295 & 1.013 & 0.284 & 0.964 & 0.296 & 1.019 & 0.294 & 1.011 & 0.296 & 1.022 \\
\hline 0.255 & 1.001 & 0.260 & 1.030 & 0.257 & 1.011 & 0.268 & 1.071 & 0.247 & 0.961 & 0.273 & 1.098 & 0.241 & 0.931 \\
\hline 0.380 & 0.996 & 0.369 & 0.953 & 0.386 & 1.025 & 0.354 & 0.890 & 0.395 & 1.062 & 0.361 & 0.919 & 0.398 & 1.075 \\
\hline 0.176 & 1.005 & 0.180 & 1.030 & 0.177 & 1.009 & 0.182 & 1.046 & 0.170 & 0.967 & 0.187 & 1.080 & 0.169 & 0.955 \\
\hline 0.489 & 0.998 & 0.485 & 0.982 & 0.496 & 1.025 & 0.473 & 0.935 & 0.497 & 1.032 & 0.482 & 0.970 & 0.496 & 1.027 \\
\hline 0 & 0.000 & 0.122 & 0.983 & 0.122 & 0.983 & 0.123 & 0.992 & 0.125 & 1.010 & 0.117 & 0.940 & 0.126 & 1.024 \\
\hline 1 . & - & 0.564 & 1.012 & 0.560 & 0.995 & 0.561 & 0.999 & 0.560 & 0.994 & 0.564 & 1.010 & 0.559 & 0.992 \\
\hline 0.372 & 1.008 & 1 & - & 0 & 0.000 & 0.382 & 1.050 & 0.362 & 0.967 & 0.386 & 1.069 & 0.360 & 0.956 \\
\hline 0.231 & 0.997 & 0 & 0.000 & 1 & - & 0.228 & 0.984 & 0.233 & 1.008 & 0.239 & 1.044 & 0.229 & 0.988 \\
\hline 0.259 & 1.001 & 0.267 & 1.043 & 0.255 & 0.983 & 1 . & - & 0 & 0.000 & 0.277 & 1.097 & 0.244 & 0.928 \\
\hline 0.431 & 0.995 & 0.422 & 0.962 & 0.434 & 1.011 & 0 & 0.000 & 1 & - & 0.413 & 0.928 & 0.445 & 1.058 \\
\hline 0.239 & 1.006 & 0.248 & 1.055 & 0.246 & 1.042 & 0.254 & 1.088 & 0.228 & 0.945 & & - & 0 & 0.000 \\
\hline 0.437 & 0.994 & 0.426 & 0.953 & 0.434 & 0.983 & 0.414 & 0.905 & 0.453 & 1.060 & 0 & 0.000 & 1 . & - \\
\hline 0.445 & 1.007 & 0.457 & 1.058 & 0.447 & 1.015 & 0.468 & 1.105 & 0.427 & 0.938 & 0.479 & 1.154 & 0.420 & 0.910 \\
\hline 0.236 & 1.001 & 0.232 & 0.978 & 0.240 & 1.022 & 0.218 & 0.900 & 0.246 & 1.057 & 0.223 & 0.931 & 0.246 & 1.058 \\
\hline 0.285 & 1.001 & 0.291 & 1.029 & 0.283 & 0.991 & 0.301 & 1.083 & 0.276 & 0.955 & 0.300 & 1.074 & 0.275 & 0.954 \\
\hline 0.179 & 0.996 & 0.180 & 1.000 & 0.184 & 1.031 & 0.174 & 0.961 & 0.185 & 1.039 & 0.178 & 0.985 & 0.184 & 1.030 \\
\hline 0.256 & 0.999 & 0.265 & 1.047 & 0.257 & 1.004 & 0.276 & 1.105 & 0.245 & 0.942 & 0.276 & 1.106 & 0.240 & 0.915 \\
\hline 0.393 & 1.001 & 0.383 & 0.959 & 0.391 & 0.994 & 0.373 & 0.920 & 0.407 & 1.060 & 0.370 & 0.908 & 0.408 & 1.066 \\
\hline 0.241 & 1.001 & 0.247 & 1.033 & 0.244 & 1.014 & 0.252 & 1.060 & 0.236 & 0.974 & 0.256 & 1.081 & 0.232 & 0.950 \\
\hline 0.394 & 0.996 & 0.389 & 0.976 & 0.399 & 1.019 & 0.382 & 0.948 & 0.403 & 1.036 & 0.388 & 0.974 & 0.399 & 1.019 \\
\hline 0.398 & 1.003 & 0.409 & 1.046 & 0.402 & 1.016 & 0.422 & 1.107 & 0.383 & 0.941 & 0.427 & 1.130 & 0.377 & 0.916 \\
\hline 0.252 & 0.999 & 0.245 & 0.964 & 0.252 & 1.002 & 0.237 & 0.921 & 0.262 & 1.053 & 0.240 & 0.937 & 0.263 & 1.061 \\
\hline 0.224 & 1.005 & 0.232 & 1.051 & 0.223 & 0.998 & 0.240 & 1.099 & 0.214 & 0.948 & 0.242 & 1.108 & 0.210 & 0.923 \\
\hline 0.422 & 0.998 & 0.416 & 0.970 & 0.425 & 1.009 & 0.406 & 0.933 & 0.432 & 1.039 & 0.410 & 0.948 & 0.433 & 1.043 \\
\hline 0.218 & 1.005 & 0.226 & 1.051 & 0.214 & 0.978 & 0.242 & 1.146 & 0.204 & 0.919 & 0.235 & 1.106 & 0.201 & 0.905 \\
\hline 0.311 & 0.996 & 0.312 & 0.997 & 0.315 & 1.013 & 0.307 & 0.978 & 0.316 & 1.018 & 0.308 & 0.980 & 0.314 & 1.010 \\
\hline 0.181 & 1.000 & 0.186 & 1.032 & 0.180 & 0.995 & 0.193 & 1.081 & 0.175 & 0.956 & 0.191 & 1.064 & 0.174 & 0.954 \\
\hline 0.519 & 0.996 & 0.515 & 0.982 & 0.523 & 1.015 & 0.507 & 0.950 & 0.530 & 1.040 & 0.508 & 0.954 & 0.529 & 1.038 \\
\hline 0.097 & 1.002 & 0.095 & 0.980 & 0.096 & 0.986 & 0.097 & 1.008 & 0.097 & 0.998 & 0.097 & 1.004 & 0.097 & 1.002 \\
\hline 0.628 & 0.997 & 0.624 & 0.978 & 0.633 & 1.019 & 0.615 & 0.942 & 0.636 & 1.031 & 0.621 & 0.967 & 0.635 & 1.025 \\
\hline 0.419 & 0.945 & 0.392 & 0.843 & 0.436 & 1.014 & 0.384 & 0.816 & 0.476 & 1.188 & 0.393 & 0.849 & 0.477 & 1.193 \\
\hline 0.581 & 1.059 & 0.608 & 1.186 & 0.564 & 0.986 & 0.616 & 1.226 & 0.524 & 0.841 & 0.607 & 1.178 & 0.523 & 0.838 \\
\hline 0.208 & 1.016 & 0.248 & 1.278 & 0.236 & 1.194 & 0.278 & 1.492 & 0.163 & 0.752 & 0.343 & 2.025 & 0.117 & 0.515 \\
\hline 0.159 & 0.949 & 0.176 & 1.067 & 0.137 & 0.795 & 0.225 & 1.457 & 0.153 & 0.909 & 0.138 & 0.805 & 0.178 & 1.086 \\
\hline 0.259 & 1.040 & 0.253 & 1.007 & 0.220 & 0.840 & 0.216 & 0.820 & 0.242 & 0.951 & 0.191 & 0.705 & 0.281 & 1.163 \\
\hline 0.165 & 0.967 & 0.119 & 0.661 & 0.158 & 0.918 & 0.156 & 0.902 & 0.186 & 1.118 & 0.133 & 0.751 & 0.175 & 1.038 \\
\hline 0.104 & 1.026 & 0.097 & 0.953 & 0.119 & 1.198 & 0.076 & 0.731 & 0.118 & 1.179 & 0.116 & 1.158 & 0.127 & 1.288 \\
\hline 0.064 & 0.900 & 0.066 & 0.939 & 0.099 & 1.461 & 0.032 & 0.432 & 0.091 & 1.318 & 0.052 & 0.733 & 0.082 & 1.185 \\
\hline 0.041 & 1.176 & 0.041 & 1.168 & 0.030 & 0.858 & 0.017 & 0.469 & 0.047 & 1.363 & 0.025 & 0.713 & 0.039 & 1.110 \\
\hline
\end{tabular}




\begin{tabular}{|c|c|c|c|c|c|c|c|c|c|c|c|c|c|}
\hline Friendly & Friendly_odds & Unfriendly & Unfriendly_odds & Healed & Healed_odds & Stimulated & Stimulated_odds & Open & Open_odds & Exclusive & Exclusive_odds & Want to reside & \begin{tabular}{|l|} 
Want to \\
reside_odds
\end{tabular} \\
\hline 0.210 & 0.974 & 0.222 & 1.044 & 0.210 & 0.973 & 0.222 & 1.046 & 0.212 & 0.983 & 0.222 & 1.045 & 0.216 & 1.007 \\
\hline 0.163 & 0.922 & 0.178 & 1.026 & 0.171 & 0.977 & 0.175 & 1.010 & 0.160 & 0.904 & 0.183 & 1.062 & 0.165 & 0.940 \\
\hline 0.097 & 0.936 & 0.104 & 1.019 & 0.102 & 0.997 & 0.105 & 1.023 & 0.096 & 0.924 & 0.106 & 1.036 & 0.097 & 0.945 \\
\hline 0.373 & 0.910 & 0.411 & 1.067 & 0.383 & 0.950 & 0.401 & 1.021 & 0.366 & 0.880 & 0.414 & 1.081 & 0.377 & 0.924 \\
\hline 0.088 & 0.988 & 0.096 & 1.086 & 0.083 & 0.936 & 0.093 & 1.057 & 0.088 & 0.993 & 0.092 & 1.037 & 0.090 & 1.017 \\
\hline 0.350 & 1.048 & 0.331 & 0.963 & 0.347 & 1.035 & 0.335 & 0.981 & 0.352 & 1.058 & 0.329 & 0.956 & 0.347 & 1.032 \\
\hline 0.290 & 0.989 & 0.298 & 1.031 & 0.290 & 0.993 & 0.296 & 1.022 & 0.280 & 0.946 & 0.298 & 1.028 & 0.289 & 0.984 \\
\hline 0.267 & 1.067 & 0.243 & 0.937 & 0.264 & 1.050 & 0.250 & 0.973 & 0.271 & 1.089 & 0.244 & 0.946 & 0.264 & 1.051 \\
\hline 0.361 & 0.921 & 0.406 & 1.113 & 0.362 & 0.925 & 0.397 & 1.071 & 0.352 & 0.885 & 0.400 & 1.084 & 0.368 & 0.948 \\
\hline 0.183 & 1.057 & 0.168 & 0.950 & 0.182 & 1.044 & 0.170 & 0.964 & 0.183 & 1.053 & 0.168 & 0.949 & 0.179 & 1.027 \\
\hline 0.480 & 0.964 & 0.506 & 1.067 & 0.478 & 0.953 & 0.500 & 1.044 & 0.476 & 0.949 & 0.499 & 1.040 & 0.484 & 0.980 \\
\hline 0.119 & 0.960 & 0.127 & 1.028 & 0.120 & 0.969 & 0.125 & 1.012 & 0.120 & 0.964 & 0.128 & 1.039 & 0.122 & 0.982 \\
\hline 0.563 & 1.008 & 0.562 & 1.003 & 0.562 & 1.001 & 0.560 & 0.994 & 0.561 & 0.998 & 0.562 & 1.001 & 0.562 & 1.002 \\
\hline 0.382 & 1.052 & 0.364 & 0.973 & 0.378 & 1.034 & 0.370 & 0.998 & 0.383 & 1.057 & 0.360 & 0.960 & 0.379 & 1.038 \\
\hline 0.233 & 1.011 & 0.235 & 1.022 & 0.230 & 0.991 & 0.237 & 1.034 & 0.232 & 1.004 & 0.230 & 0.995 & 0.234 & 1.015 \\
\hline 0.273 & 1.077 & 0.239 & 0.899 & 0.274 & 1.083 & 0.250 & 0.955 & 0.278 & 1.106 & 0.246 & 0.933 & 0.270 & 1.061 \\
\hline 0.416 & 0.938 & 0.451 & 1.080 & 0.418 & 0.946 & 0.445 & 1.057 & 0.413 & 0.925 & 0.447 & 1.065 & 0.423 & 0.963 \\
\hline 0.257 & 1.107 & 0.226 & 0.933 & 0.251 & 1.071 & 0.236 & 0.985 & 0.257 & 1.104 & 0.225 & 0.926 & 0.252 & 1.077 \\
\hline 0.416 & 0.912 & 0.457 & 1.081 & 0.424 & 0.945 & 0.448 & 1.041 & 0.410 & 0.891 & 0.456 & 1.073 & 0.421 & 0.931 \\
\hline 1 & - & 0 & 0.000 & 0.462 & 1.082 & 0.429 & 0.945 & 0.472 & 1.124 & 0.420 & 0.909 & 0.459 & 1.065 \\
\hline 0 & 0.000 & 1 & - & 0.222 & 0.923 & 0.252 & 1.092 & 0.218 & 0.904 & 0.251 & 1.086 & 0.230 & 0.968 \\
\hline 0.297 & 1.062 & 0.268 & 0.918 & 1 & - & 0 & 0.000 & 0.300 & 1.074 & 0.272 & 0.938 & 0.292 & 1.033 \\
\hline 0.174 & 0.962 & 0.192 & 1.085 & 0 & 0.000 & 1 & - & 0.172 & 0.949 & 0.189 & 1.060 & 0.181 & 1.008 \\
\hline 0.273 & 1.091 & 0.237 & 0.902 & 0.270 & 1.071 & 0.245 & 0.943 & & - & 0 & 0.000 & 0.268 & 1.062 \\
\hline 0.372 & 0.916 & 0.418 & 1.110 & 0.375 & 0.927 & 0.412 & 1.083 & 0 & 0.000 & & - & 0.384 & 0.962 \\
\hline 0.250 & 1.049 & 0.235 & 0.968 & 0.247 & 1.032 & 0.242 & 1.007 & 0.252 & 1.061 & 0.235 & 0.969 & & - \\
\hline 0.386 & 0.966 & 0.407 & 1.054 & 0.383 & 0.954 & 0.404 & 1.041 & 0.387 & 0.966 & 0.405 & 1.042 & 0 & 0.000 \\
\hline 0.418 & 1.088 & 0.378 & 0.922 & 0.413 & 1.064 & 0.388 & 0.960 & 0.422 & 1.106 & 0.380 & 0.928 & 0.412 & 1.062 \\
\hline 0.241 & 0.942 & 0.265 & 1.073 & 0.243 & 0.956 & 0.262 & 1.056 & 0.236 & 0.918 & 0.265 & 1.069 & 0.245 & 0.965 \\
\hline 0.238 & 1.087 & 0.208 & 0.915 & 0.234 & 1.064 & 0.214 & 0.950 & 0.243 & 1.116 & 0.210 & 0.925 & 0.233 & 1.059 \\
\hline 0.411 & 0.952 & 0.438 & 1.062 & 0.412 & 0.956 & 0.432 & 1.039 & 0.406 & 0.934 & 0.435 & 1.052 & 0.415 & 0.969 \\
\hline 0.234 & 1.098 & 0.196 & 0.875 & 0.231 & 1.081 & 0.201 & 0.902 & 0.241 & 1.142 & 0.201 & 0.904 & 0.228 & 1.061 \\
\hline 0.306 & 0.972 & 0.323 & 1.049 & 0.306 & 0.970 & 0.325 & 1.061 & 0.307 & 0.978 & 0.320 & 1.037 & 0.313 & 1.006 \\
\hline 0.190 & 1.057 & 0.170 & 0.926 & 0.190 & 1.060 & 0.175 & 0.959 & 0.192 & 1.074 & 0.172 & 0.938 & 0.186 & 1.034 \\
\hline 0.507 & 0.950 & 0.539 & 1.080 & 0.507 & 0.949 & 0.539 & 1.079 & 0.505 & 0.944 & 0.535 & 1.064 & 0.517 & 0.989 \\
\hline 0.097 & 0.998 & 0.095 & 0.984 & 0.097 & 1.006 & 0.094 & 0.973 & 0.095 & 0.984 & 0.098 & 1.010 & 0.096 & 0.991 \\
\hline 0.621 & 0.965 & 0.642 & 1.058 & 0.618 & 0.955 & 0.637 & 1.033 & 0.618 & 0.955 & 0.638 & 1.039 & 0.624 & 0.980 \\
\hline 0.413 & 0.923 & 0.421 & 0.953 & 0.438 & 1.020 & 0.427 & 0.975 & 0.426 & 0.971 & 0.427 & 0.977 & 0.405 & 0.892 \\
\hline 0.587 & 1.083 & 0.579 & 1.049 & 0.562 & 0.981 & 0.573 & 1.026 & 0.574 & 1.029 & 0.573 & 1.024 & 0.595 & 1.121 \\
\hline 0.295 & 1.624 & 0.135 & 0.603 & 0.263 & 1.382 & 0.175 & 0.824 & 0.310 & 1.744 & 0.131 & 0.584 & 0.269 & 1.422 \\
\hline 0.158 & 0.941 & 0.141 & 0.822 & 0.195 & 1.212 & 0.188 & 1.162 & 0.184 & 1.130 & 0.166 & 0.998 & 0.180 & 1.102 \\
\hline 0.245 & 0.968 & 0.234 & 0.911 & 0.247 & 0.978 & 0.170 & 0.608 & 0.241 & 0.947 & 0.221 & 0.844 & 0.203 & 0.758 \\
\hline 0.135 & 0.763 & 0.178 & 1.060 & 0.141 & 0.803 & 0.156 & 0.900 & 0.137 & 0.774 & 0.214 & 1.327 & 0.153 & 0.881 \\
\hline 0.091 & 0.880 & 0.135 & 1.382 & 0.098 & 0.960 & 0.140 & 1.443 & 0.048 & 0.441 & 0.126 & 1.280 & 0.092 & 0.890 \\
\hline 0.049 & 0.682 & 0.116 & 1.732 & 0.036 & 0.492 & 0.115 & 1.721 & 0.058 & 0.811 & 0.083 & 1.202 & 0.068 & 0.963 \\
\hline 0.026 & 0.746 & 0.061 & 1.779 & 0.020 & 0.558 & 0.056 & 1.621 & 0.022 & 0.621 & 0.059 & 1.713 & 0.036 & 1.028 \\
\hline
\end{tabular}




\begin{tabular}{|c|c|c|c|c|c|c|c|c|c|c|c|c|c|}
\hline \begin{tabular}{|l|}
$\begin{array}{l}\text { Do not want to } \\
\text { reside }\end{array}$ \\
\end{tabular} & \begin{tabular}{|l|}
$\begin{array}{l}\text { Do not want to } \\
\text { reside_odds }\end{array}$ \\
\end{tabular} & Warm & Warm_odds & Aloof & Aloof_odds & Fascinating & Fascinating_odds & Not fascinating & \begin{tabular}{|l|} 
Not \\
fascinating_odds
\end{tabular} & Want to play & $\begin{array}{l}\text { Want to } \\
\text { play_odds }\end{array}$ & \begin{tabular}{|l|}
$\begin{array}{l}\text { Want to examine } \\
\text { deliberately }\end{array}$ \\
\end{tabular} & $\begin{array}{l}\text { Want to examine } \\
\text { deliberately_odds }\end{array}$ \\
\hline 0.216 & 1.009 & 0.212 & 0.982 & 0.216 & 1.006 & 0.214 & 0.996 & 0.214 & 0.999 & 0.213 & 0.988 & 0.220 & 1.034 \\
\hline 0.174 & 1.002 & 0.164 & 0.934 & 0.183 & 1.062 & 0.160 & 0.904 & 0.179 & 1.035 & 0.162 & 0.915 & 0.174 & 1.002 \\
\hline 0.101 & 0.986 & 0.096 & 0.924 & 0.109 & 1.072 & 0.096 & 0.925 & 0.105 & 1.025 & 0.093 & 0.903 & 0.102 & 0.995 \\
\hline 0.400 & 1.018 & 0.373 & 0.908 & 0.417 & 1.092 & 0.367 & 0.885 & 0.408 & 1.051 & 0.362 & 0.866 & 0.396 & 1.002 \\
\hline 0.091 & 1.030 & 0.089 & 1.000 & 0.088 & 0.989 & 0.090 & 1.011 & 0.089 & 1.003 & 0.089 & 1.002 & 0.092 & 1.046 \\
\hline 0.334 & 0.974 & 0.349 & 1.045 & 0.328 & 0.952 & 0.353 & 1.061 & 0.333 & 0.970 & 0.356 & 1.075 & 0.337 & 0.990 \\
\hline 0.292 & 1.001 & 0.288 & 0.980 & 0.300 & 1.042 & 0.284 & 0.961 & 0.296 & 1.021 & 0.278 & 0.935 & 0.290 & 0.991 \\
\hline 0.252 & 0.985 & 0.266 & 1.063 & 0.245 & 0.950 & 0.270 & 1.082 & 0.248 & 0.967 & 0.271 & 1.090 & 0.253 & 0.989 \\
\hline 0.390 & 1.042 & 0.364 & 0.931 & 0.398 & 1.075 & 0.353 & 0.889 & 0.394 & 1.057 & 0.345 & 0.859 & 0.387 & 1.029 \\
\hline 0.172 & 0.976 & 0.182 & 1.046 & 0.170 & 0.961 & 0.183 & 1.054 & 0.172 & 0.976 & 0.184 & 1.062 & 0.171 & 0.974 \\
\hline 0.497 & 1.030 & 0.482 & 0.969 & 0.497 & 1.032 & 0.476 & 0.948 & 0.497 & 1.028 & 0.470 & 0.927 & 0.495 & 1.021 \\
\hline 0.125 & 1.012 & 0.122 & 0.981 & 0.125 & 1.009 & 0.120 & 0.966 & 0.125 & 1.012 & 0.123 & 0.995 & 0.126 & 1.020 \\
\hline 0.560 & 0.994 & 0.562 & 1.002 & 0.561 & 0.997 & 0.564 & 1.009 & 0.561 & 0.997 & 0.563 & 1.006 & 0.560 & 0.994 \\
\hline 0.364 & 0.975 & 0.380 & 1.045 & 0.361 & 0.961 & 0.384 & 1.063 & 0.363 & 0.971 & 0.385 & 1.065 & 0.369 & 0.994 \\
\hline 0.234 & 1.015 & 0.234 & 1.013 & 0.231 & 1.001 & 0.231 & 0.999 & 0.232 & 1.007 & 0.227 & 0.976 & 0.233 & 1.011 \\
\hline 0.250 & 0.956 & 0.275 & 1.085 & 0.244 & 0.925 & 0.278 & 1.102 & 0.249 & 0.949 & 0.287 & 1.154 & 0.255 & 0.983 \\
\hline 0.441 & 1.037 & 0.415 & 0.935 & 0.448 & 1.070 & 0.413 & 0.926 & 0.441 & 1.040 & 0.402 & 0.884 & 0.437 & 1.024 \\
\hline 0.234 & 0.975 & 0.256 & 1.097 & 0.226 & 0.935 & 0.257 & 1.104 & 0.231 & 0.960 & 0.256 & 1.097 & 0.235 & 0.981 \\
\hline 0.443 & 1.018 & 0.415 & 0.910 & 0.457 & 1.080 & 0.411 & 0.893 & 0.449 & 1.046 & 0.403 & 0.866 & 0.441 & 1.013 \\
\hline 0.433 & 0.962 & 0.465 & 1.095 & 0.423 & 0.923 & 0.471 & 1.122 & 0.430 & 0.950 & 0.476 & 1.141 & 0.434 & 0.966 \\
\hline 0.244 & 1.042 & 0.225 & 0.937 & 0.249 & 1.070 & 0.221 & 0.915 & 0.244 & 1.045 & 0.213 & 0.873 & 0.244 & 1.043 \\
\hline 0.277 & 0.961 & 0.295 & 1.051 & 0.275 & 0.950 & 0.299 & 1.069 & 0.278 & 0.964 & 0.301 & 1.083 & 0.279 & 0.970 \\
\hline 0.184 & 1.029 & 0.176 & 0.972 & 0.188 & 1.054 & 0.173 & 0.956 & 0.184 & 1.027 & 0.167 & 0.913 & 0.187 & 1.051 \\
\hline 0.251 & 0.972 & 0.272 & 1.083 & 0.240 & 0.918 & 0.279 & 1.121 & 0.246 & 0.948 & 0.284 & 1.152 & 0.253 & 0.980 \\
\hline 0.403 & 1.042 & 0.375 & 0.927 & 0.412 & 1.086 & 0.370 & 0.907 & 0.404 & 1.049 & 0.362 & 0.879 & 0.403 & 1.042 \\
\hline 0 & 0.000 & 0.250 & 1.051 & 0.235 & 0.968 & 0.252 & 1.062 & 0.237 & 0.977 & 0.253 & 1.068 & 0.242 & 1.004 \\
\hline 1 & - & 0.388 & 0.974 & 0.403 & 1.036 & 0.386 & 0.964 & 0.401 & 1.026 & 0.381 & 0.945 & 0.401 & 1.026 \\
\hline 0.391 & 0.972 & 1 & - & 0 & 0.000 & 0.421 & 1.099 & 0.387 & 0.957 & 0.430 & 1.141 & 0.394 & 0.984 \\
\hline 0.257 & 1.027 & 0 & 0.000 & 1 & - & 0.238 & 0.927 & 0.259 & 1.039 & 0.229 & 0.881 & 0.255 & 1.017 \\
\hline 0.218 & 0.971 & 0.237 & 1.078 & 0.212 & 0.935 & 1 & - & 0 & 0.000 & 0.248 & 1.146 & 0.219 & 0.978 \\
\hline 0.430 & 1.027 & 0.411 & 0.953 & 0.435 & 1.048 & 0 & 0.000 & & - & 0.400 & 0.909 & 0.427 & 1.016 \\
\hline 0.210 & 0.956 & 0.235 & 1.105 & 0.199 & 0.893 & 0.240 & 1.135 & 0.207 & 0.937 & & - & 0 & 0.000 \\
\hline 0.317 & 1.023 & 0.309 & 0.984 & 0.315 & 1.015 & 0.307 & 0.976 & 0.315 & 1.012 & 0 & 0.000 & 1 & - \\
\hline 0.176 & 0.966 & 0.189 & 1.053 & 0.173 & 0.947 & 0.191 & 1.068 & 0.176 & 0.965 & 0.195 & 1.093 & 0.178 & 0.978 \\
\hline 0.528 & 1.035 & 0.510 & 0.963 & 0.531 & 1.047 & 0.506 & 0.947 & 0.527 & 1.030 & 0.500 & 0.923 & 0.530 & 1.043 \\
\hline 0.096 & 0.996 & 0.097 & 0.999 & 0.097 & 1.007 & 0.096 & 0.990 & 0.097 & 1.004 & 0.097 & 1.002 & 0.095 & 0.984 \\
\hline 0.636 & 1.032 & 0.622 & 0.972 & 0.636 & 1.031 & 0.618 & 0.954 & 0.635 & 1.027 & 0.615 & 0.941 & 0.634 & 1.020 \\
\hline 0.449 & 1.068 & 0.383 & 0.814 & 0.490 & 1.257 & 0.408 & 0.902 & 0.451 & 1.076 & 0.359 & 0.734 & 0.417 & 0.936 \\
\hline 0.551 & 0.937 & 0.617 & 1.228 & 0.510 & 0.796 & 0.592 & 1.109 & 0.549 & 0.929 & 0.641 & 1.363 & 0.583 & 1.069 \\
\hline 0.191 & 0.912 & 0.283 & 1.529 & 0.149 & 0.680 & 0.305 & 1.699 & 0.169 & 0.785 & 0.304 & 1.691 & 0.186 & 0.885 \\
\hline 0.145 & 0.848 & 0.168 & 1.012 & 0.156 & 0.929 & 0.178 & 1.083 & 0.150 & 0.882 & 0.189 & 1.167 & 0.183 & 1.121 \\
\hline 0.228 & 0.878 & 0.229 & 0.886 & 0.234 & 0.908 & 0.243 & 0.955 & 0.247 & 0.976 & 0.268 & 1.088 & 0.210 & 0.791 \\
\hline 0.199 & 1.215 & 0.155 & 0.896 & 0.189 & 1.134 & 0.134 & 0.758 & 0.190 & 1.143 & 0.162 & 0.942 & 0.179 & 1.064 \\
\hline 0.098 & 0.959 & 0.088 & 0.849 & 0.137 & 1.405 & 0.060 & 0.562 & 0.121 & 1.215 & 0.033 & 0.305 & 0.101 & 0.987 \\
\hline 0.096 & 1.402 & 0.058 & 0.821 & 0.078 & 1.121 & 0.046 & 0.635 & 0.084 & 1.212 & 0.031 & 0.417 & 0.098 & 1.441 \\
\hline 0.044 & 1.266 & 0.019 & 0.518 & 0.057 & 1.661 & 0.035 & 0.985 & 0.040 & 1.151 & 0.014 & 0.386 & 0.044 & 1.255 \\
\hline
\end{tabular}


(IJACSA) International Journal of Advanced Computer Science and Applications,

Vol. 10, No. 5, 2019

\begin{tabular}{|c|c|c|c|c|c|c|c|c|c|c|c|c|c|}
\hline & & & & & & & & Gender & & & & Age & \\
\hline Lively & Lively_odds & Calm & Calm_odds & \begin{tabular}{|l|} 
Atmosphere of \\
urban
\end{tabular} & $\begin{array}{l}\text { Atmosphere of } \\
\text { urban_odds }\end{array}$ & \begin{tabular}{|l} 
Atmosphere of \\
rural area
\end{tabular} & $\begin{array}{l}\text { Atmosphere of } \\
\text { rural area_odds }\end{array}$ & Male & Male_odds & Female & Female_odds & 10 th & 10th_odds \\
\hline 0.211 & 0.978 & 0.219 & 1.025 & 0.211 & 0.978 & 0.215 & 1.001 & 0.181 & 0.807 & 0.240 & 1.159 & 0.180 & 0.802 \\
\hline 0.169 & 0.965 & 0.176 & 1.017 & 0.179 & 1.038 & 0.175 & 1.005 & 0.195 & 1.150 & 0.158 & 0.890 & 0.070 & 0.357 \\
\hline 0.101 & 0.982 & 0.103 & 1.010 & 0.103 & 1.003 & 0.102 & 0.994 & 0.132 & 1.328 & 0.080 & 0.764 & 0.044 & 0.402 \\
\hline 0.379 & 0.933 & 0.401 & 1.024 & 0.404 & 1.034 & 0.399 & 1.016 & 0.449 & 1.247 & 0.355 & 0.839 & 0.214 & 0.416 \\
\hline 0.085 & 0.957 & 0.091 & 1.033 & 0.084 & 0.945 & 0.090 & 1.018 & 0.058 & 0.637 & 0.112 & 1.294 & 0.085 & 0.954 \\
\hline 0.349 & 1.044 & 0.335 & 0.982 & 0.335 & 0.980 & 0.336 & 0.986 & 0.306 & 0.857 & 0.365 & 1.120 & 0.403 & 1.314 \\
\hline 0.288 & 0.979 & 0.293 & 1.004 & 0.298 & 1.030 & 0.293 & 1.006 & 0.300 & 1.038 & 0.286 & 0.972 & 0.278 & 0.932 \\
\hline 0.265 & 1.053 & 0.250 & 0.977 & 0.254 & 0.998 & 0.252 & 0.985 & 0.250 & 0.976 & 0.258 & 1.019 & 0.363 & 1.664 \\
\hline 0.361 & 0.920 & 0.390 & 1.043 & 0.382 & 1.006 & 0.388 & 1.032 & 0.388 & 1.033 & 0.375 & 0.975 & 0.253 & 0.552 \\
\hline 0.182 & 1.044 & 0.171 & 0.972 & 0.176 & 1.006 & 0.173 & 0.987 & 0.169 & 0.954 & 0.180 & 1.035 & 0.233 & 1.431 \\
\hline 0.478 & 0.954 & 0.496 & 1.026 & 0.487 & 0.991 & 0.495 & 1.020 & 0.488 & 0.992 & 0.491 & 1.006 & 0.441 & 0.821 \\
\hline 0.121 & 0.975 & 0.126 & 1.018 & 0.124 & 1.003 & 0.125 & 1.008 & 0.109 & 0.864 & 0.135 & 1.107 & 0.085 & 0.657 \\
\hline 0.561 & 1.000 & 0.560 & 0.995 & 0.563 & 1.005 & 0.561 & 0.998 & 0.543 & 0.930 & 0.575 & 1.058 & 0.569 & 1.030 \\
\hline 0.380 & 1.042 & 0.367 & 0.985 & 0.364 & 0.973 & 0.367 & 0.986 & 0.335 & 0.857 & 0.397 & 1.121 & 0.447 & 1.379 \\
\hline 0.230 & 0.994 & 0.233 & 1.009 & 0.228 & 0.984 & 0.233 & 1.009 & 0.233 & 1.011 & 0.230 & 0.992 & 0.266 & 1.202 \\
\hline 0.275 & 1.090 & 0.252 & 0.966 & 0.260 & 1.006 & 0.253 & 0.971 & 0.229 & 0.853 & 0.281 & 1.121 & 0.350 & 1.547 \\
\hline 0.416 & 0.937 & 0.440 & 1.034 & 0.431 & 0.998 & 0.437 & 1.020 & 0.474 & 1.188 & 0.399 & 0.875 & 0.342 & 0.685 \\
\hline 0.251 & 1.072 & 0.233 & 0.969 & 0.239 & 1.001 & 0.235 & 0.984 & 0.217 & 0.883 & 0.255 & 1.094 & 0.399 & 2.120 \\
\hline 0.422 & 0.936 & 0.446 & 1.030 & 0.439 & 1.002 & 0.442 & 1.016 & 0.483 & 1.196 & 0.404 & 0.870 & 0.251 & 0.429 \\
\hline 0.464 & 1.087 & 0.432 & 0.956 & 0.442 & 0.997 & 0.437 & 0.976 & 0.423 & 0.922 & 0.458 & 1.064 & 0.637 & 2.212 \\
\hline 0.222 & 0.921 & 0.245 & 1.049 & 0.233 & 0.982 & 0.241 & 1.027 & 0.230 & 0.965 & 0.241 & 1.027 & 0.155 & 0.593 \\
\hline 0.299 & 1.069 & 0.278 & 0.965 & 0.287 & 1.008 & 0.280 & 0.976 & 0.288 & 1.016 & 0.283 & 0.988 & 0.365 & 1.443 \\
\hline 0.174 & 0.960 & 0.186 & 1.045 & 0.175 & 0.970 & 0.182 & 1.015 & 0.177 & 0.982 & 0.182 & 1.013 & 0.154 & 0.828 \\
\hline 0.272 & 1.082 & 0.249 & 0.963 & 0.253 & 0.980 & 0.252 & 0.977 & 0.252 & 0.978 & 0.260 & 1.017 & 0.388 & 1.838 \\
\hline 0.373 & 0.919 & 0.404 & 1.050 & 0.396 & 1.015 & 0.398 & 1.023 & 0.387 & 0.978 & 0.397 & 1.017 & 0.251 & 0.517 \\
\hline 0.248 & 1.038 & 0.240 & 0.992 & 0.239 & 0.988 & 0.239 & 0.990 & 0.226 & 0.917 & 0.253 & 1.066 & 0.315 & 1.451 \\
\hline 0.383 & 0.954 & 0.401 & 1.028 & 0.393 & 0.995 & 0.399 & 1.019 & 0.409 & 1.063 & 0.383 & 0.954 & 0.367 & 0.888 \\
\hline 0.415 & 1.075 & 0.390 & 0.969 & 0.397 & 0.997 & 0.394 & 0.983 & 0.352 & 0.823 & 0.433 & 1.154 & 0.549 & 1.840 \\
\hline 0.241 & 0.941 & 0.257 & 1.029 & 0.254 & 1.011 & 0.255 & 1.015 & 0.285 & 1.183 & 0.227 & 0.871 & 0.183 & 0.666 \\
\hline 0.236 & 1.073 & 0.217 & 0.965 & 0.221 & 0.989 & 0.219 & 0.977 & 0.210 & 0.926 & 0.233 & 1.058 & 0.332 & 1.727 \\
\hline 0.411 & 0.950 & 0.429 & 1.025 & 0.425 & 1.008 & 0.427 & 1.017 & 0.441 & 1.075 & 0.410 & 0.946 & 0.348 & 0.727 \\
\hline 0.234 & 1.097 & 0.209 & 0.950 & 0.218 & 1.004 & 0.213 & 0.971 & 0.180 & 0.792 & 0.246 & 1.173 & 0.322 & 1.710 \\
\hline 0.307 & 0.973 & 0.319 & 1.030 & 0.308 & 0.979 & 0.315 & 1.011 & 0.301 & 0.946 & 0.321 & 1.042 & 0.283 & 0.869 \\
\hline 1 & - & 0 & 0.000 & 0.181 & 0.997 & 0.178 & 0.979 & 0.175 & 0.961 & 0.186 & 1.030 & 0.234 & 1.385 \\
\hline 0 & 0.000 & 1 & - & 0.515 & 0.983 & 0.524 & 1.018 & 0.516 & 0.985 & 0.522 & 1.011 & 0.444 & 0.737 \\
\hline 0.096 & 0.997 & 0.096 & 0.991 & 1 & - & 0 & 0.000 & 0.098 & 1.015 & 0.096 & 0.988 & 0.094 & 0.973 \\
\hline 0.618 & 0.956 & 0.634 & 1.024 & 0 & 0.000 & & - & 0.629 & 1.001 & 0.629 & 0.999 & 0.585 & 0.831 \\
\hline 0.419 & 0.944 & 0.430 & 0.987 & 0.439 & 1.025 & 0.433 & 1.001 & & - & 0 & 0.000 & 0.433 & 1.000 \\
\hline 0.581 & 1.059 & 0.570 & 1.013 & 0.561 & 0.976 & 0.567 & 0.999 & 0 & 0.000 & & - & 0.567 & 1.000 \\
\hline 0.266 & 1.401 & 0.175 & 0.822 & 0.200 & 0.969 & 0.191 & 0.914 & 0.205 & 1.000 & 0.205 & 1.000 & & - \\
\hline 0.197 & 1.232 & 0.171 & 1.037 & 0.147 & 0.865 & 0.150 & 0.882 & 0.166 & 1.000 & 0.166 & 1.000 & 0 & 0.000 \\
\hline 0.252 & 1.003 & 0.224 & 0.859 & 0.251 & 1.000 & 0.248 & 0.981 & 0.251 & 1.000 & 0.251 & 1.000 & 0 & 0.000 \\
\hline 0.135 & 0.763 & 0.182 & 1.085 & 0.219 & 1.365 & 0.184 & 1.097 & 0.170 & 1.000 & 0.170 & 1.000 & 0 & 0.000 \\
\hline 0.088 & 0.855 & 0.110 & 1.087 & 0.117 & 1.173 & 0.106 & 1.050 & 0.102 & 1.000 & 0.102 & 1.000 & 0 & 0.000 \\
\hline 0.045 & 0.626 & 0.094 & 1.371 & 0.034 & 0.471 & 0.085 & 1.234 & 0.070 & 1.000 & 0.070 & 1.000 & 0 & 0.000 \\
\hline 0.017 & 0.465 & 0.044 & 1.275 & 0.031 & 0.885 & 0.037 & 1.045 & 0.035 & 1.000 & 0.035 & 1.000 & 0 & 0.000 \\
\hline
\end{tabular}




\begin{tabular}{|c|c|c|c|c|c|c|c|c|c|c|c|}
\hline 20th & 20st_odds & 30th & 30st_odds & 40 th & 40st_odds & 50 th & 50st_odds & 60th & 60st_odds & More than70 & \begin{tabular}{|l} 
More \\
than70_odds
\end{tabular} \\
\hline 0.262 & 1.301 & 0.196 & 0.891 & 0.212 & 0.983 & 0.170 & 0.751 & 0.240 & 1.156 & 0.419 & 2.640 \\
\hline 0.229 & 1.411 & 0.182 & 1.057 & 0.230 & 1.417 & 0.240 & 1.502 & 0.127 & 0.688 & 0.095 & 0.496 \\
\hline 0.158 & 1.642 & 0.117 & 1.155 & 0.084 & 0.799 & 0.148 & 1.516 & 0.077 & 0.728 & 0.095 & 0.915 \\
\hline 0.402 & 1.025 & 0.437 & 1.183 & 0.473 & 1.372 & 0.531 & 1.729 & 0.371 & 0.900 & 0.419 & 1.101 \\
\hline 0.066 & 0.726 & 0.092 & 1.041 & 0.075 & 0.827 & 0.050 & 0.545 & 0.168 & 2.068 & 0.216 & 2.833 \\
\hline 0.362 & 1.102 & 0.354 & 1.069 & 0.259 & 0.681 & 0.297 & 0.824 & 0.305 & 0.856 & 0.333 & 0.973 \\
\hline 0.238 & 0.760 & 0.279 & 0.937 & 0.298 & 1.032 & 0.460 & 2.065 & 0.233 & 0.736 & 0.323 & 1.158 \\
\hline 0.258 & 1.016 & 0.219 & 0.818 & 0.238 & 0.914 & 0.197 & 0.719 & 0.204 & 0.748 & 0.220 & 0.825 \\
\hline 0.305 & 0.714 & 0.374 & 0.972 & 0.443 & 1.294 & 0.546 & 1.954 & 0.556 & 2.041 & 0.399 & 1.079 \\
\hline 0.156 & 0.872 & 0.180 & 1.033 & 0.144 & 0.792 & 0.186 & 1.074 & 0.120 & 0.642 & 0.124 & 0.664 \\
\hline 0.419 & 0.753 & 0.482 & 0.971 & 0.516 & 1.110 & 0.552 & 1.282 & 0.651 & 1.944 & 0.533 & 1.188 \\
\hline 0.141 & 1.158 & 0.125 & 1.009 & 0.154 & 1.293 & 0.109 & 0.861 & 0.142 & 1.170 & 0.124 & 0.999 \\
\hline 0.537 & 0.906 & 0.578 & 1.070 & 0.546 & 0.940 & 0.574 & 1.054 & 0.509 & 0.810 & 0.656 & 1.492 \\
\hline 0.390 & 1.090 & 0.372 & 1.008 & 0.260 & 0.597 & 0.354 & 0.934 & 0.349 & 0.913 & 0.430 & 1.282 \\
\hline 0.190 & 0.782 & 0.202 & 0.843 & 0.215 & 0.912 & 0.272 & 1.240 & 0.327 & 1.617 & 0.199 & 0.828 \\
\hline 0.350 & 1.545 & 0.222 & 0.818 & 0.237 & 0.892 & 0.194 & 0.691 & 0.116 & 0.378 & 0.124 & 0.405 \\
\hline 0.398 & 0.871 & 0.416 & 0.936 & 0.473 & 1.182 & 0.500 & 1.317 & 0.556 & 1.651 & 0.581 & 1.824 \\
\hline 0.198 & 0.790 & 0.181 & 0.708 & 0.187 & 0.734 & 0.272 & 1.191 & 0.178 & 0.693 & 0.172 & 0.663 \\
\hline 0.469 & 1.132 & 0.490 & 1.230 & 0.452 & 1.058 & 0.549 & 1.558 & 0.513 & 1.349 & 0.485 & 1.205 \\
\hline 0.421 & 0.915 & 0.432 & 0.957 & 0.352 & 0.684 & 0.394 & 0.820 & 0.309 & 0.563 & 0.333 & 0.629 \\
\hline 0.200 & 0.809 & 0.220 & 0.913 & 0.248 & 1.065 & 0.314 & 1.482 & 0.389 & 2.060 & 0.409 & 2.238 \\
\hline 0.334 & 1.257 & 0.280 & 0.977 & 0.237 & 0.778 & 0.275 & 0.950 & 0.145 & 0.427 & 0.162 & 0.483 \\
\hline 0.203 & 1.165 & 0.121 & 0.630 & 0.165 & 0.899 & 0.248 & 1.506 & 0.295 & 1.905 & 0.285 & 1.821 \\
\hline 0.284 & 1.149 & 0.246 & 0.946 & 0.207 & 0.755 & 0.120 & 0.395 & 0.211 & 0.775 & 0.162 & 0.558 \\
\hline 0.392 & 0.997 & 0.345 & 0.814 & 0.494 & 1.508 & 0.489 & 1.477 & 0.465 & 1.346 & 0.656 & 2.954 \\
\hline 0.261 & 1.113 & 0.195 & 0.760 & 0.217 & 0.871 & 0.217 & 0.873 & 0.233 & 0.955 & 0.247 & 1.035 \\
\hline 0.343 & 0.802 & 0.357 & 0.853 & 0.463 & 1.320 & 0.380 & 0.940 & 0.538 & 1.787 & 0.495 & 1.503 \\
\hline 0.402 & 1.017 & 0.363 & 0.862 & 0.363 & 0.862 & 0.343 & 0.790 & 0.331 & 0.749 & 0.210 & 0.401 \\
\hline 0.237 & 0.921 & 0.234 & 0.908 & 0.279 & 1.151 & 0.340 & 1.530 & 0.280 & 1.155 & 0.409 & 2.055 \\
\hline 0.238 & 1.090 & 0.216 & 0.956 & 0.176 & 0.745 & 0.131 & 0.526 & 0.145 & 0.592 & 0.220 & 0.981 \\
\hline 0.381 & 0.838 & 0.416 & 0.969 & 0.472 & 1.220 & 0.503 & 1.380 & 0.505 & 1.394 & 0.485 & 1.282 \\
\hline 0.247 & 1.180 & 0.232 & 1.084 & 0.207 & 0.939 & 0.071 & 0.276 & 0.095 & 0.376 & 0.086 & 0.338 \\
\hline 0.343 & 1.151 & 0.261 & 0.776 & 0.329 & 1.078 & 0.309 & 0.984 & 0.436 & 1.705 & 0.388 & 1.398 \\
\hline 0.215 & 1.237 & 0.181 & 1.002 & 0.144 & 0.761 & 0.157 & 0.843 & 0.116 & 0.595 & 0.086 & 0.425 \\
\hline 0.535 & 1.065 & 0.463 & 0.796 & 0.556 & 1.157 & 0.560 & 1.176 & 0.695 & 2.102 & 0.656 & 1.766 \\
\hline 0.086 & 0.874 & 0.097 & 1.000 & 0.124 & 1.326 & 0.112 & 1.172 & 0.047 & 0.463 & 0.086 & 0.878 \\
\hline 0.566 & 0.769 & 0.620 & 0.963 & 0.679 & 1.247 & 0.657 & 1.130 & 0.764 & 1.906 & 0.656 & 1.127 \\
\hline 0.433 & 1.000 & 0.433 & 1.000 & 0.433 & 1.000 & 0.433 & 1.000 & 0.433 & 1.000 & 0.433 & 1.000 \\
\hline 0.567 & 1.000 & 0.567 & 1.000 & 0.567 & 1.000 & 0.567 & 1.000 & 0.567 & 1.000 & 0.567 & 1.000 \\
\hline 0 & 0.000 & 0 & 0.000 & 0 & 0.000 & 0 & 0.000 & 0 & 0.000 & 0 & 0.000 \\
\hline 1 & - & 0 & 0.000 & 0 & 0.000 & 0 & 0.000 & 0 & 0.000 & 0 & 0.000 \\
\hline 0 & 0.000 & 1 & - & 0 & 0.000 & 0 & 0.000 & 0 & 0.000 & 0 & 0.000 \\
\hline 0 & 0.000 & 0 & 0.000 & 1 & - & 0 & 0.000 & 0 & 0.000 & 0 & 0.000 \\
\hline 0 & 0.000 & 0 & 0.000 & 0 & 0.000 & 1 & - & 0 & 0.000 & 0 & 0.000 \\
\hline 0 & 0.000 & 0 & 0.000 & 0 & 0.000 & 0 & 0.000 & 1 & - & 0 & 0.000 \\
\hline 0 & 0.000 & 0 & 0.000 & 0 & 0.000 & 0 & 0.000 & 0 & 0.000 & & - \\
\hline
\end{tabular}

